\title{
Modification of Dietary Habits for Prevention of Gout in Japanese People: Gout and Macronutrient Intake
}

\author{
Takashi Koguchi \\ Department of Human Education, Kokugakuin Tochigi Junior College, Tochigi, Japan \\ Email address: \\ echo130@nifty.com

\section{To cite this article:} \\ Takashi Koguchi. Modification of Dietary Habits for Prevention of Gout in Japanese People: Gout and Macronutrient Intake. American \\ Journal of Health Research. Vol. 9, No. 5, 2021, pp. 128-142. doi: 10.11648/j.ajhr.20210905.13
}

Received: August 1, 2021; Accepted: September 1, 2021; Published: September 10, 2021

\begin{abstract}
In Japan, most of gout patients are adults, and the prevalence of gout has increased markedly since the 1960s. This phenomenon is thought to be attributed to the westernization of the Japanese diet since 1955. Monitoring the intake of nutrients and foods in Japanese people is essential in the prevention of gout. The objective of this article is to propose a preventive method for gout through the evaluation of recent dietary habits in Japanese people. In this article, the author suggests what macronutrient intake is important for the prevention of gout in Japanese people referencing the results of clinical research reported. The author used the data of the Comprehensive Survey of Living Conditions in Japan for the number of gout patients (1986-2016) and the data of the National Health and Nutrition Survey in Japan (1946-2017) for the intake of macronutrients. The relationship between the number of gout patients and macronutrient intake in Japanese people was examined. Modification of macronutrient intake for the prevention of gout in Japanese people (especially adults) is suggested as follows: energy-providing nutrient balance (percentages of proteins, fats, and carbohydrates in total energy intake) should be within the range of the tentative dietary goal for preventing lifestyle-related diseases (DG); reduce fat (especially animal fat) intake and maintain the mean ratio of energy intake from saturated fatty acids in total energy intake (Saturated fatty acids/Energy) within the range of the tentative dietary goal for preventing lifestyle-related diseases (DG); limiting or decreasing intake of fat (especially animal fat); replacement of saturated fatty acids (e.g., dairy fats, meat fat) with mono- and polyunsaturated fatty acids (especially n-3 polyunsaturated fatty acids) (e.g., macadamia nuts, almonds, peanuts and peanut butter, olive oil, canola oil, avocados); avoidance of excessive intake of saturated fatty acids and cholesterol; pay attention to sucrose and fructose intake; increase intake of dietary fiber; and maintenance of good hydration.
\end{abstract}

Keywords: Dietary Fiber, Dietary Habits, Food, Gout, Hyperuricemia, Macronutrient, Uric Acid

\section{Introduction}

In Japan, most of gout patients are adults [1], and the prevalence of gout has increased markedly since the 1960s [1-5]. The number of gout patients was higher in men than in women [1, 3, 5-11]. Compared to the Japanese diet in 1950, in the Japanese diet in 2016, consumption of rice and potatoes decreased, whereas intake of wheat, legumes, seeds and nuts, seaweed, vegetables, fruit, meat, seafood, eggs, milk and dairy products, oils and fats, seasoning and spices increased [12]. This phenomenon is thought to be attributed to the westernization of the Japanese diet since 1955. In Japan, the number of patients with gout, hypertension, diabetes mellitus, dyslipidemia, and kidney disease increased between 1998 and 2016, respectively and the number of patients with myocardial infarction tended to increase between 1998 and 2016 [1]. The Japanese Society of Gout and Uric \& Nucleic Acids Guidelines for Management of Hyperuricemia and Gout [7] has stated that hyperuricemia and/or gout is associated with chronic kidney disease (CKD), urolithiasis, hypertension, and cardiovascular disease (CVD). Therefore, it is important to establish dietary habits that have beneficial effects in preventing not only gout but also some chronic diseases and/or comorbidities of gout (e.g., hypertension, diabetes mellitus, dyslipidemia, cardiovascular disease).

In the previous report [13], the author described the trends in the number of gout patients with changes in the Japanese diet. This article shows the relationship between the number of gout patients and macronutrient intake in Japanese people and suggests modification of macronutrient intake for the 
prevention of gout in Japanese people referencing the results of clinical research.

\section{Methods}

\subsection{The Number of Gout Patients}

The number of gout patients was estimated in the Comprehensive Survey of Living Conditions performed by the Ministry of Health, Labour and Welfare in Japan (1986-2016) [1]. The Comprehensive Survey of Living Conditions was based on self-reporting by residents. This article showed the rate of hospital visits due to gout from 1986 to 2016 based on the Comprehensive Survey of Living Conditions. Hakoda and Kasagi [14] confirmed that the trends in the number of gout patients in Japan in 2013 and 2016 reported by the Comprehensive Survey of Living Conditions were almost equal to those reported by the database of health insurance claims with gout diagnosed by physicians.

\subsection{The Trends in Nutrient or Food Intake in Japanese People}

The intake of nutrients or foods was searched in the National Health and Nutrition Survey, Japan (1946-2017) performed by the Ministry of Health, Labour and Welfare in Japan $[12,15,16]$.

Data were extracted from the series of Japanese National Nutrition Surveys that have been carried out every year throughout Japan since 1946 [16]. In these surveys, food consumption by families enrolled in the study was assessed by weighing food items consumed on three consecutive weekdays (until 1994) or one weekday (from 1995).

The daily nutrient or food intakes of Japanese people are shown as the mean values reported by the National Health and Nutrition Survey Japan (1946-2017) [12].

\subsection{Dietary Reference Intakes for Japanese People}

The Ministry of Health, Labour and Welfare in Japan [15] evaluated the intake of nutrients as described below: (1) the estimated average requirement (EAR) indicates the amount that would meet the nutrient requirements of $50 \%$ of the population; (2) the recommended dietary allowance (RDA) indicates the amount that would meet the nutrient requirement of most of the population; (3) the adequate intake (AI) indicates the amount adequate to maintain a certain level of nutritional status; (4) the tolerable upper intake level (UL) was determined for the purpose of avoiding adverse health effects due to excessive intake; and (5) the tentative dietary goal for preventing lifestyle-related diseases (DG) was developed for the purpose of prevention of lifestyle-related diseases.

\subsection{Food Composition}

The food composition was extracted from a standard tables of food composition in Japan -2020- (Eighth Revised Edition) of the Council for Science and Technology, Ministry of Education, Culture, Sports, Science and Technology in Japan. the Ministry of Education, Culture, Sports, Science and Technology [17] and the National Institutes of Health in the U.S. Department of Health \& Human Services [18].

\subsection{Statistical Analysis}

The correlation efficient and the significance of the correlation between the number of gout patients and nutrient intake in 1986, 1989, 1992, 1995, 1998, 2001, 2004, 2007, 2010, 2013, and 2016 were analyzed by Pearson Product Moment Correlation. A SigmaPlot 12.0 software program (version 12.0, Systat Software Inc, San Jose, CA) was used for statistical analysis. Differences were considered significant at $\mathrm{p}<0.05$.

\section{Relationship Between the Number of Gout Patients and Macronutrient Intake}

The results on the correlation between the number of gout patients and macronutrient intake in Japanese people are shown in Table 1.

\subsection{Energy}

The daily energy intake of Japanese people in 2016 was lower compared to that in 1960, 1965, 1975, 1986, 1989, 1992 1995, 1998, 2001, 2004, 2007, and 2013 and was higher compared to that in 2010 (1960: $2096 \mathrm{kcal} /$ day; 1965: 2184 $\mathrm{kcal} /$ day; 1975: $2188 \mathrm{kcal} /$ day; 1986: $2075 \mathrm{kcal} /$ day; 1989: $2061 \mathrm{kcal} /$ day; 1992: $2058 \mathrm{kcal} /$ day; 1995: $2042 \mathrm{kcal} /$ day; 1998: $1979 \mathrm{kcal} /$ day; 2001: $1954 \mathrm{kcal} /$ day; 2004: 1902 $\mathrm{kcal} /$ day; 2007: $1898 \mathrm{kcal} /$ day; 2010: $1849 \mathrm{kcal} /$ day; 2013: $1873 \mathrm{kcal} /$ day; 2016: $1865 \mathrm{kcal} /$ day). In Japanese men and women in 2016, the mean daily intake of energy for men (20-49 years) and women (20-49 years) was 2092-2122 $\mathrm{kcal} /$ day and 1631-1694 kcal/day, respectively, and was below the estimation of energy requirement of low physical activity levels [physical activity levels: low: $2300 \mathrm{kcal} /$ day; medium: 2650-2700 kcal/day; high: $3050 \mathrm{kcal} /$ day among men; low: 1700-1750 kcal/day; medium: 2000-2050 kcal/day; high: $2300-2350 \mathrm{kcal} /$ day among women] [15]. In Japanese men and women in 2016, the mean daily intake of energy for men ( $\geq 50$ years) and women ( $\geq 50$ years) was $2092-2122 \mathrm{kcal} /$ day and 1631-1694 kcal/day, respectively, and was within the estimation of energy requirement of low physical activity levels, and below the estimation of energy requirement of medium physical activity levels [physical activity levels: low: 1800-2200 kcal/day; medium: 2100-2600 kcal/day; high: $2750-2950 \mathrm{kcal} /$ day among men; low: $1400-1650 \mathrm{kcal} /$ day; medium: 1650-2190 kcal/day; high: 2100-2250 kcal/day among women] [15].

The daily consumption of energy was negatively correlated with the number of gout patients in 1986-2016 $(\mathrm{r}=-0.984$, $\mathrm{p}=0.0000000514$ ). The daily consumption of energy did not show a significant correlation with the number of gout patients in the adult population (aged $\geq 20$ years) in 2004-2016 ( $\mathrm{r}=$ 
$-0.610, \mathrm{p}=0.275)$, with the number of gout patients in adult men (aged $\geq 20$ years) in 2004-2016 $(r=-0.610, p=0.275)$, and with the number of gout patients in adult women (aged $\geq 20$ years $)$ in 2004-2016 $(\mathrm{r}=0.826, \mathrm{p}=0.0847)$.

Proper energy intake for gout patients [7] or diabetes mellitus patients [19] is recommended in each guideline. The National Kidney Foundation's Kidney Disease Outcomes Quality Initiative (KDOQI) [20] has recommended energy intake of $25-35 \mathrm{kcal} / \mathrm{kg}$ body weight per day in adults with chronic kidney disease (CKD) (CKD stages 1-5D) or posttransplantation.

\subsection{Carbohydrates}

\subsubsection{Carbohydrate}

The daily carbohydrate intake of Japanese people in 2016 was lower compared to that in 1959, 1965, 1975, 1986, 1989, 1992, 1995, 1998, 2001, 2004, 2007, 2010, and 2013 (1959: 405 g/day; 1965: 384 g/day; 1975: 337 g/day; 1986: 295 g/day; 1989: 290 g/day; 1992: 289 g/day; 1995: 280 g/day; 1998: 271 g/day; 2001: 274 g/day; 2004: 266 g/day; 2007: 264 g/day; 2010: 258 g/day; 2013: 259 g/day; 2016: 252.8 g/day). The Ministry of Health, Labour and Welfare in Japan [15] has not set the recommended dietary allowance (RDA) for the daily carbohydrate intake in Japanese people.

The daily carbohydrate intake was negatively correlated with the number of gout patients in 1986-2016 $(\mathrm{r}=-0.978$, $\mathrm{p}=0.00000215$ ), with the number of gout patients in the adult population (aged $\geq 20$ years) in 2004-2016 ( $\mathrm{r}=-0.909$, $\mathrm{p}=0.0327$ ), and with the number of gout patients in adult men (aged $\geq 20$ years) in 2004-2016 $(\mathrm{r}=-0.909, \mathrm{p}=0.0323)$. The daily carbohydrate intake tended to be positively correlated with the number of gout patients in adult women (aged $\geq 20$ years $)$ in 2004-2016 ( $\mathrm{r}=0.864, \mathrm{p}=0.0590)$. This result suggests that the correlation of daily carbohydrate intake with the number of gout patients tends to vary with gender and is stronger in adult men than in adult women. The daily carbohydrate intake of adult men and women tended to increase as age increased.

\subsubsection{Sugars and Fructose}

Effects of sucrose, glucose and fructose on serum uric acid (SUA) levels and hyperuricemia risk are reviewed in detail by Koguchi [21].

\section{Fructose}

The Ministry of Health, Labour and Welfare in Japan has not investigated the daily fructose intake. In a study incorporating data from the US National Health and Nutrition Examination Survey (NHANES) and the National Food Consumption Survey, the estimated average dietary intake of fructose increased $12 \mathrm{~g}$ /day from 1977 to 2005 (1977: 37 $\mathrm{g} /$ day; 2005: $49 \mathrm{~g} /$ day) [22]. The predominant sources of fructose in the diet are nonalcoholic beverages, which occupy $46 \%$ of total fructose intake [22]. In a systematic review and meta-analysis of controlled feeding trials, high fructose intake (213-219 g/day) under hypercaloric feeding conditions $(+35 \%$ excess energy) raised serum uric acid (SUA) concentrations in people with and without diabetes mellitus [23]. Therefore,
Wang et al. [23] have stated that high fructose intake (213-219 $\mathrm{g} /$ day) under hypercaloric feeding conditions $(+35 \%$ excess energy) leads to increased risk of hyperuricemia and gout.

Acute oral or intravenous administration of fructose rapidly increased SUA levels through accentuated degradation of purine nucleotides in humans [24-28] and increased purine synthesis de novo $[26,29]$. An intravenous administration of fructose $(0.5 \mathrm{~g} / \mathrm{kg} / \mathrm{h})$ for 2 hours increased blood lactate concentrations, which may be attributable to decrease UA excretion via urate transporter 1 (URAT1/SLC22A12) [30, 31]. Therefore, fructose intake increases SUA level via both decreased UA excretion and increased UA production [31]. Caliceti et al. [32] have stated that it is not yet possible to conclude whether fructose intake alone is the main contributor to increased blood UA concentration.

In epidemiological studies, increased fructose intake was associated with increased SUA concentrations [33, 34], hyperuricemia risk [33-35], and gout risk [35-39]. Higher intake of foods high in fructose was associated with increased SUA concentrations [33, 40-45], hyperuricemia risk [46], and gout risk [40]. These results suggest that decrease in daily intake of fructose-rich foods (e.g., high-fructose corn syrup and sugar-sweetened beverages, soft drinks) in Japanese people is essential for the prevention of gout.

The 2020 American College of Rheumatology (ACR) Guideline [47] has conditionally recommended for limiting high-fructose for patients with gout, regardless of disease activity. Japanese Society of Gout and Uric \& Nucleic Acids Guidelines [7] has recommended avoidance of fructose overdose in patients of gout.

\section{Sugars}

The daily intake of sugar and sweetener of Japanese people in 2016 was lower compared to that in 2001, 2004, 2007, 2010, and 2013 (2001: $7.2 \mathrm{~g}$ /day; 2004: $7.1 \mathrm{~g} /$ day; 2007: $6.7 \mathrm{~g} /$ day; 2010: 6.7 g/day; 2013: 6.6 g/day; 2016: 6.5 g/day). The Ministry of Health, Labour and Welfare in Japan [15] has not set the tentative dietary goal for preventing lifestyle-related diseases (DG) for the daily intake of sugars (monosaccharides, disaccharides, sugar alcohols) in Japanese people.

The daily sugar and sweetener intake was negatively correlated with the number of gout patients in 2001-2016 (r= $-0.870, p=0.0242$ ). The daily sugar and sweetener intake did not show a significant correlation with the number of gout patients in the adult population (aged $\geq 20$ years) in 2004-2016 $(\mathrm{r}=-0.729, \mathrm{p}=0.162)$, and with the number of gout patients in adult women (aged $\geq 20$ years) in 2004-2016 ( $\mathrm{r}=0.782$, $\mathrm{p}=0.118$ ). The daily sugar and sweetener intake was negatively correlated with the number of gout patients in adult men (aged $\geq 20$ years) in 2004-2016 $(r=-0.915, p=0.0295)$. This result suggests that correlation of daily sugar and sweetener intake with the number of gout patients varies with gender.

Sucrose intake $(1.5 \mathrm{~g} / \mathrm{kg}$ of body weight) increased plasma UA concentrations in healthy subjects through increase in purine degradation [48]. In epidemiological studies, added sugars were related to serum uric acid (SUA) concentration among Whites [49]. Increased intake of sugars [50], added 
sugars which are fructose-containing sugars, sucrose and high fructose corn syrup [46] was associated with increased hyperuricemia risk. Therefore, increased the daily sugars intake do not appear to be appropriate for the prevention of gout.

The 2012 American College of Rheumatology (ACR) Guidelines for Management of Gout [51] have recommended limiting intake of table sugar in all gout patients.

Tappy et al. [50] have proposed to set a maximum limit to the intake of total sugars containing fructose (sucrose, glucose fructose syrups, honey or other syrups, and natural concentrates, etc.) of $100 \mathrm{~g} /$ day [50].

\subsubsection{Dietary Fiber}

The daily intake of dietary fiber of Japanese people in 2016 was lower compared to that in 1951, 1955, 1960, 1966, 1975, 1986, 1989, 1992, 1998, 2001, and 2007 and was higher compared to that in 2004, and 2010 and was about the same as that in 2013 (1951: $23.3 \mathrm{~g} /$ day; 1955: $23.0 \mathrm{~g} /$ day; 1960: 19.9 g/day; 1966: $18.1 \mathrm{~g} /$ day; 1975: $18.3 \mathrm{~g} /$ day; 1986: $16.6 \mathrm{~g} /$ day; 1989: 16.4 g/day; 1992: 16.4 g/day; 1998: 15.0 g/day; 2001: 14.6 g/day; 2004: 13.9 g/day; 2007: 14.6 g/day; 2010: 14.0 g/day; 2013: 14.2 g/day; 2016: 14.2 g/day). In Japanese men and women in 2016, the daily dietary fiber intake for men (aged $\geq 15$ years) and women (aged $\geq 15$ years) was 12.5-16.9 $\mathrm{g} /$ day and 11.3-16.1 g/day, respectively, and was below the tentative dietary goal for preventing lifestyle-related diseases (DG) [men (aged 15-17 years): $\geq 19 \mathrm{~g} /$ day; men (aged 18-64 years): $\geq 21 \mathrm{~g} /$ day; men (aged $\geq 65$ years): $\geq 20 \mathrm{~g} /$ day; women (aged 15-64 years): $\geq 18 \mathrm{~g}$ /day; women (aged $\geq 65$ years): $\geq 17$ $\mathrm{g} /$ day][15]. The daily dietary fiber intake of adult men and women tended to increase as age increased.

The daily intake of dietary fiber was negatively correlated with the number of gout patients in 1986-2016 $(r=-0.946$, $\mathrm{p}=0.000036$ ). This result suggests that the daily dietary fiber intake below the tentative dietary goal for preventing lifestyle-related diseases (DG) is related to the increase in the number of gout patients. The daily intake of dietary fiber did not show a significant correlation with the number of gout patients in the adult population (aged $\geq 20$ years) in 2004-2016 $(\mathrm{r}=-0.133, \mathrm{p}=0.831)$, with the number of gout patients in adult men (aged $\geq 20$ years) in 2004-2016 $(r=-0.0701, p=0.911)$, and with the number of gout patients in adult women (aged $\geq$ 20 years $)$ in 2004-2016 ( $\mathrm{r}=0.108, \mathrm{p}=0.862)$. Japanese men and women should increase their daily dietary fiber intake.

In a clinical trial, dietary fiber decreased serum uric acid (SUA) concentrations [52, 53]. In epidemiological studies, increased dietary fiber intake was associated with decreased SUA concentrations [54-57], hyperuricemia risk [55, 56, 58, 59], and gout risk [60]. Dietary fiber intake may prevent gout through reduced SUA concentrations and decreased hyperuricemia risk.

In an experimental model of gout in mice, which are made by injection of monosodium urate crystals into the knee joint, a high-fiber diet $(5 \%$ cellulose $+10 \%$ pectin) controlled the inflammatory response to monosodium urate crystals by favoring the resolution of the inflammatory response [61]. In the same mouse model of gout, a pectin-rich fiber diet increased serum acetate concentrations and showed reduced joint destruction and decreased joint dysfunction (hypernociception) and interleukin-1 $\beta$ (IL-1 $\beta$ ) production, compared with the cellulose diet [61]. Therefore, high intake of dietary fiber had a positive effect on the resolution of a gout flare in an experimental model of mice with gout [61].

Dietary fiber, such as inulin $[62,63]$ and konjac glucomannan $[64,65]$, inhibits xanthine oxidase activity and suppresses uric acid (UA) production. Dietary fiber suppresses digestion and/or absorption of dietary purine [21, 66-73]. Agarose suppresses digestion and/or absorption of dietary purine and increases the renal excretion efficiency of UA [72]. Inulin increased short chain fatty acids (SCFAs) concentrations (acetate, propionate and butyrate concentrations) and SCFAs-producing bacteria (e.g., Akkermansia, Ruminococcus, Bifidobacterium, Parasutterella) in the feces and modulated gut microbiota, as well as affecting production of gut microbiota-derived SCFAs [63]. Inulin improved intestinal barrier function, alleviated the inflammatory state, and reduced SUA levels in Uox-knockout (urate oxidase) mice [63]. The mechanism may be related to SCFAs, especially propionate and butyrate, providing ATP to the cells of the intestinal wall to show beneficial effects on UA excretion [74, 75], and butyrate improves metabolism of UA through lowering UA concentrations in the colonic mucosa [76]. Future investigations are needed to clarify how dietary fiber suppresses elevation of SUA concentrations, other than the above-mentioned mechanisms.

Increased dietary fiber intake was associated with lower serum C-reactive protein concentrations [77-80], serum high-sensitivity C-reactive protein concentrations [81], plasma interleukin-6 (IL-6) concentrations, and plasma tumor necrosis factor-alpha receptor 2 (TNF- $\alpha-\mathrm{R} 2)$ concentrations [82]. Therefore, Ma et al. [79, 82] have stated that a diet high in fiber may play a role in reducing inflammation. Increased dietary fiber intake (>16.82 g [79], >18.3 g [78], > $20 \mathrm{~g}$ [80]) was significantly associated with lower serum or plasma C-reactive protein (CRP) concentrations. Dietary fiber increases production of SCFAs, which are acetate, propionate, and butyrate, by increasing bacteria that are beneficial to health $[83,84]$. The mechanism responsible for the anti-inflammatory effect of dietary fiber has not been fully elucidated but might involve the production of SCFAs by colonic fermentation in rodents $[63,85,86]$. Dietary fiber also acts as a carrier of dietary polyphenols [87-89]; that is to say, most of the polyphenols traverse the small intestine linked to dietary fiber, and they release the fiber matrix in the colon by the action of the bacterial microbiota, producing metabolites and an antioxidant environment [87-89] and exert their anti-inflammatory effects [90-92]. Foods high in both dietary fiber and polyphenols that may have the effect of suppressing elevated SUA concentrations are nuts (almonds, hazelnuts, pistachio nuts), fruit (apples, blackberries, red raspberries, pears), and vegetables (broccoli, globe artichokes) [17, 18]. It is speculated that simultaneous intake of foods high in both dietary fiber and polyphenol compounds, which have the 
anti-inflammatory properties, may lead to prevention of chronic diseases related to inflammation including gout.

Epidemiological studies have reported that increased dietary fiber intake was significantly associated with decreased risks of chronic kidney disease (CKD) [93-96], obesity [83, 97-102], diabetes mellitus [83, 97-100, 103, 104], hypertension [93, 97, 99, 105], cardiovascular disease (CVD) [100, 106, 107], coronary artery disease (CAD) and coronary heart disease (CHD) [97, 108-112], stroke [97], CVD in adults with CKD [113], ischemic cardiovascular disease (iCVD) [114], myocardial infarction [115], cancer [100], all-cause mortality [116, 117], CVD-cause mortality [116], respiratory disease-cause mortality [116], and injury-cause mortality [116].

The guidelines have recommended increased intake of fiber for healthy adults for CVD prevention [106, 107], urolithiasis patients [118], and diabetes mellitus patients [19, 119]. The Japanese clinical practice guideline for diabetes 2019 [19] has stated that the daily dietary fiber intake for diabetes patients is more than $20 \mathrm{~g}$. The 2016 European Guidelines on cardiovascular disease prevention in clinical practice [106] has recommended that the daily dietary fiber intake for all individuals is $30-45 \mathrm{~g}$.

Judging from the data of food composition [17, 18], it is important for Japanese people (aged $\geq 15$ years) to eat seeds and nuts (pumpkin seeds, chia seeds, almonds, pistachio nuts, hazelnuts, peanuts), whole grains (high fiber-bran ready-to-eat cereals, shredded wheat ready-to-eat cereals, whole grain bread, oats, barley, rye), legumes (navy beans, small white beans, yellow beans, cranberry beans, adzuki beans, French beans, split peas, chickpeas, lentils, pinto beans), seaweed, mushrooms (wood ear, shiitake mushrooms, maitake mushrooms), potatoes (konjac, potato with skin), fruit (avocados, apples, raspberries, blackberries, prunes, oranges, bananas, guavas), and vegetables (artichokes, pumpkins, tomatoes, broccoli, carrots, sweet corn, pears) to take in more dietary fiber to reach the tentative dietary goal for preventing lifestyle-related diseases (DG).

\subsubsection{The Mean Ratio of Energy Intake from Carbohydrate in Total Energy Intake (Carbohydrate/Energy)}

The mean ratio of energy intake from carbohydrate in total energy intake (Carbohydrate/Energy) in 1986, 1989, 1992, 1995, 1998, 2001, 2004, 2007, 2010, 2013, and 2016 were $57.8-60.3 \%$ of energy. The mean ratio of energy intake from carbohydrate in total energy intake (Carbohydrate/Energy) in 2016 was lower compared to that in 1975, 1980, 1986, 1989, 1992, 2001, 2004, 2007, 2010, and 2013 and was about the same as that in 1995 and 1998 (1975: 63.1\%; 1980: 61.5\%; 1986: $60.3 \%$; 1989: 58.7\%; 1992: 58.9\%; 1995: 57.8\%; 1998: $57.8 \%$; 2001: 59.7\%; 2004: 59.7\%; 2007: 59.3\%; 2010: 59.4\%; 2013: 58.9\%; 2016: 57.8\%). In Japanese men and women in 2016, the mean ratio of energy intake from carbohydrate in total energy intake (Carbohydrate/Energy) of Japanese men (aged $\geq 1$ year) and women (aged $\geq 1$ year) was $56.8-60.7 \%$ of energy and $54.4-58.9 \%$ of energy, respectively, and was within the tentative dietary goal for preventing life-style related diseases (DG) [men (aged $\geq 1$ year): 50-65\% of energy; women (aged $\geq 1$ year): 50-65\% of energy] [15].

The mean ratio of energy intake from carbohydrate in total energy intake (Carbohydrate/Energy) did not show a significant correlation with the number of gout patients in $1986-2016(r=-0.058, p=0.865)$, and with the number of gout patients in adult women (aged $\geq 20$ years) in 2004-2016 $(r=0.591, p=0.294)$. Whereas the mean ratio of energy intake from carbohydrate in total energy intake (Carbohydrate/Energy) tended to be negatively correlated with the number of gout patients in the adult population (aged $\geq 20$ years $)$ in 2004-2016 $(\mathrm{r}=-0.875, \mathrm{p}=0.0518)$. The mean ratio of energy intake from carbohydrate in total energy intake (Carbohydrate/Energy) was negatively correlated with the number of gout patients in adult men (aged $\geq 20$ years) in $2004-2016(r=-0.899, p=0.0377)$. This result suggests that the correlation of the mean ratio of energy intake from carbohydrate in total energy intake (Carbohydrate/Energy) with the number of gout patients varies with gender.

The ideal balance of the caloric ratio of protein, fat, and carbohydrate for healthy life is protein: $15 \%$, fat: $25 \%$, and carbohydrates: $60 \%$ [120]. It seems better to increase the mean ratio of energy intake from carbohydrate in total energy intake (Carbohydrate /Energy) until 60\%. In particular, intake of fiber-rich foods (e.g., whole grains, legumes, seeds and nuts, fruit, vegetables) seems to be important for the prevention of gout.

\subsection{Proteins}

\subsubsection{Total Protein}

The daily total protein intake of Japanese people in 2016 was lower compared to that in 1960, 1965, 1975, 1986, 1989, 1992, 1995, 1998, 2001, 2004, 2007, and 2013 and was higher compared to that in 2010 (1960: $69.7 \mathrm{~g} / \mathrm{day} ; 1965: 71.3 \mathrm{~g} / \mathrm{day}$; 1975: 80.0 g/day; 1986: 78.9 g/day; 1989: 80.2 g/day; 1992: 80.1 g/day; 1995: 81.5 g/day; 1998: 79.2 g/day; 2001: 73.4 g/day; 2004: 70.8 g/day; 2007: 69.8 g/day; 2010: 67.3 g/day; 2013: $68.9 \mathrm{~g} /$ day; 2016: $68.5 \mathrm{~g}$ /day). In Japanese men and women in 2016, the mean daily total protein intake for Japanese men (aged $\geq 1$ year) and women (aged $\geq 1$ year) was 45.1-79.1 g/day and 43.1-67.8 g/day, respectively, and exceeded the recommended dietary allowance (RDA) [men (aged $\geq 1$ year): 20-65 g/day; women (aged $\geq 1$ year): 20-55 $\mathrm{g} /$ day] [15].

The daily total protein intake was negatively correlated with the number of gout patients in 1986-2016 $(\mathrm{r}=-0.937$, $\mathrm{p}=0.0000215$ ). The daily intake of total protein did not show a significant correlation with the number of gout patients in the adult population (aged $\geq 20$ years) in 2004-2016 $(r=-0.559$, $\mathrm{p}=0.327$ ), and with the number of gout patients in adult men (aged $\geq 20$ years) in 2004-2016 $(r=-0.577, p=0.308)$. Whereas the daily total protein intake was positively correlated with the number of gout patients in adult women (aged $\geq 20$ years) in 2004-2016 $(\mathrm{r}=0.896, \mathrm{p}=0.0399)$. This result suggests that the correlation of daily total protein intake with the number of gout patients varies with gender.

In a prospective cohort study in a Chinese population, higher intake of total protein was associated with increased gout risk, 
whereas higher intake of soy protein was associated with decreased gout risk [121]. This population-based cohort study in a Chinese adult population (aged 45-74 years) revealed that daily total protein intake of subjects with gout was significantly higher than that of subjects without gout (subjects with gout: $15.4 \pm 2.5 \%$ energy; subjects without gout: $15.2 \pm 2.4 \%$ energy) and daily soy protein intake of subjects with gout tended to decrease compared to that of subjects without gout (subjects with gout: $1.47 \pm 0.99 \%$ energy; subjects without gout: $1.50 \pm 1.01 \%$ energy). The daily total protein intake (the mean ratio of energy intake from protein in total energy intake) of Japanese adult population (aged $\geq 40$ years) in 2016 was $14.4-15.2 \%$ energy. The daily total protein intake of Japanese adult population (aged $\geq 40$ years) was as same as that of Chinese adult population without gout (aged 45-74 years).

The Ministry of Health, Labour and Welfare in Japan [15] has not set a tolerable upper intake level (UL) for healthy individuals because there are insufficient reports of clear scientific evidence for health problems due to excessive daily intake of protein. However, excessive intake of protein can reduce renal function. A meta-analysis concluded that higher protein intake $(\geq 20 \%$ but $<35 \%$ of energy or $\geq 10 \%$ higher than a comparison intake) within the range of recommended intakes for protein was consistent with normal renal function in healthy individuals in the short term (and did not reduce renal function) [122]. In healthy adults, consuming a higher-protein diet did not cause changes in kidney function compared with lower- or normal-protein diets [123]. In healthy adult men and women, protein intake should not exceed the World Health Organization (WHO) recommendation $(0.83 \mathrm{~g} / \mathrm{kg}$ body weight/day for adults [124]).

Clinical practice guideline for nutrition in chronic kidney disease (CKD) have recommended for protein intake as follows: (1) protein restriction in CKD patients [125]; (2) protein restriction in adults with CKD (CKD stages 3-5) not on dialysis with or without diabetes [20]; and (3) protein intake of $1.0-1.2 \mathrm{~g} / \mathrm{kg}$ body weight/day in adults with CKD (CKD stages 5D) on maintenance hemodialysis or peritoneal dialysis [20]. European Association of Urology 2018 has recommended for limited daily animal protein intake (0.8-1.0 $\mathrm{g} / \mathrm{kg} /$ day) for patients with urolithiasis [118].

\subsubsection{Animal Protein}

The daily animal protein intake of Japanese people in 2016 was higher compared to that in 19601965,2010 , and 2013 and was lower compared to that in 1975, 1986, 1989, 1992, 1995, 1998, 2001, 2004, and 2007 (1960: $24.7 \mathrm{~g} /$ day; 1965: 28.5 g/day; 1975: 38.9 g/day; 1986: 40.1 g/day; 1989: 42.4 g/day; 1992: 42.5 g/day; 1995: 44.4 g/day; 1998: 42.8 g/day; 2001: 39.9 g/day; 2004: 38.0 g/day; 2007: 38.0 g/day; 2010: 36.0 g/day; 2013: $37.2 \mathrm{~g} /$ day; 2016: $37.4 \mathrm{~g} /$ day).

The daily intake of animal protein was negatively correlated with the number of gout patients in 1986-2016 $(\mathrm{r}=-0.823$, $\mathrm{p}=0.00185$ ). The daily intake of animal protein did not show a significant correlation with the number of gout patients in the adult population (aged $\geq 20$ years) in 2004-2016 ( $\mathrm{r}=-0.241$, $\mathrm{p}=0.696$ ), with the number of gout patients in adult men (aged $\geq 20$ years $)$ in 2004-2016 $(\mathrm{r}=-0.376, \mathrm{p}=0.532)$, and with the number of gout patients in adult women (aged $\geq 20$ years) in 2004-2016 ( $\mathrm{r}=0.717, \mathrm{p}=0.173)$.

In a clinical trial, animal sources of protein (e.g., casein, lactalbumin [126, 127]) decreased serum uric acid (SUA) concentrations. An increase in intake of milk and cheese seems to be important for the prevention of gout through a decrease in SUA concentrations.

\subsubsection{Vegetable Protein}

The vegetable protein is from grains, potatoes, legumes, seeds, nuts, fruit, vegetables, mushrooms, and seaweed. The daily vegetable protein intake of Japanese people in 2016 was lower compared to that in 1960, 1965, 1975, 1986, 1989, 1992, 1995, 1998, 2001, 2004, 2007, 2010, and 2013 (1960: 45.0 g/day; 1965: 42.8 g/day; 1975: 41.1 g/day; 1986: 38.8 g/day; 1989: 37.8 g/day; 1992: 37.6 g/day; 1995: $37.1 \mathrm{~g} /$ day; 1998 : $36.4 \mathrm{~g} /$ day; 2001: $33.5 \mathrm{~g} /$ day; 2004: $32.8 \mathrm{~g} /$ day; 2007: 31.8 g/day; 2010: 31.3 g/day; 2013: 31.7 g/day; 2016: 31.1 g/day).

The daily vegetable protein intake was negatively correlated with the number of gout patients in 1986-2016 (r= $-0.974, p=0.000000417$ ). The daily intake of vegetable protein did not show a significant correlation with the number of gout patients in the adult population (aged $\geq 20$ years) in 2004-2016 $(\mathrm{r}=-0.674, \mathrm{p}=0.312)$, and with the number of gout patients in adult men (aged $\geq 20$ years) in 2004-2016 ( $\mathrm{r}=-0.740$, $\mathrm{p}=0.153$ ). The daily intake of vegetable protein tended to be positively correlated with the number of gout patients in adult women (aged $\geq 20$ years) in 2004-2016 $(\mathrm{r}=0.854, \mathrm{p}=0.0656)$. This result suggests that the correlation of daily vegetable protein intake with the number of gout patients tends to vary with gender.

Vegetable sources of protein (e.g., wheat gluten [128], rice endosperm protein [129]) decreased SUA concentrations. An increase in intake of wheat gluten and rice endosperm protein seems to be important for the prevention of gout through a decrease in SUA concentrations.

\subsubsection{The Mean Ratio of Energy Intake from Protein in Total Energy Intake (Protein/Energy)}

The mean ratio of energy intake from protein in total energy intake (Protein/Energy) in 1986, 1989, 1992, 1995, 1998, 2002, $2005,2007,2010,2013$, and 2016 were $14.7-16.1 \%$ of energy. The mean ratio of energy intake from protein in total energy intake (Protein/Energy) in 2016 was higher compared to that in 1975 and 2010 and was lower compared to that in 1980, 1986, 1989, 1992, 1995, 1998, 2002, and 2005 and was about the same as that in 2007 and 2013 (1975: 14.6\%; 1980: 14.9\%; 1986: 15.2\%; 1989: 15.6\%; 1992: 15.6\%; 1995: 16.1\%; 1998: 16.1\%; 2002: 15.1\%; 2005: 15.1\%; 2007: 14.8\%; 2010: 14.7\%; 2013: $14.8 \%$; 2016: 14.8\%). In Japanese men and women in 2016, the mean ratio of energy intake from protein in total energy intake (Protein/Energy) of Japanese men (aged $\geq 1$ year) and women (aged $\geq 1$ year) was $14.1-15.0 \%$ of energy and $13.9-15.6 \%$ of energy, respectively, and was within the tentative dietary goal for preventing lifestyle-related diseases (DG) [men ( $\geq 1$ year): $13-20 \%$ of energy; women (aged $\geq 1$ year): $13-20 \%$ of energy] [15]. 
The mean ratio of energy intake from protein in total energy intake (Protein/Energy) was negatively correlated with the number of gout patients in 1986-2016 $(\mathrm{r}=-0.697, \mathrm{p}=0.0172)$. The mean ratio of energy intake from protein in total energy intake (Protein/Energy) did not show a significant correlation with the number of gout patients in the adult population (aged $\geq 20$ years) in 2004-2016 ( $\mathrm{r}=-0.405, \mathrm{p}=0.499$ ), with the number of gout patients in adult men (aged $\geq 20$ years) in 2004-2016 $(r=-0.147, p=0.813)$, and with the number of gout patients in adult women (aged $\geq 20$ years) in 2004-2016 $(\mathrm{r}=0.855, \mathrm{p}=0.0648)$.

The ideal balance of the caloric ratio of protein, fat, and carbohydrate for healthy life is protein: $15 \%$, fat: $25 \%$, and carbohydrates: $60 \%$ [120]. It seems better to increase the mean ratio of energy intake from protein in total energy intake (Protein/Energy) until 15\%.

\subsection{Fats}

\subsubsection{Total Fat}

The daily total fat intake of Japanese people in 2016 was higher compared to that in 1960, 1965, 1975, 1986, 2001, 2004, 2007, 2010, and 2013 and was lower compared to that in 1989, 1992, 1995, 1998 (1960: 24.7 g/day; 1965: 36.0 g/day; 1975: 52.0 g/day; 1986: 56.6 g/day; 1989: 58.9 g/day; 1992: 58.4 g/day; 1995: 59.9 g/day; 1998: 57.9 g/day; 2001: 55.3 g/day; 2004: 54.1 g/day; 2007: 55.1 g/day; 2010: 53.7 g/day; 2013: 55.0 g/day; 2016: 57.2 g/day). The Ministry of Health, Labour and Welfare in Japan [15] has not set the recommended dietary allowance (RDA) for the daily total fat intake in Japanese people.

The daily intake of total fat was negatively correlated with the number of gout patients in 1986-2016 ( $\mathrm{r}=-0.677$, $\mathrm{p}=0.0221$ ). The daily intake of total fat did not show a significant correlation with the number of gout patients in the adult population (aged $\geq 20$ years) in 2004-2016 ( $\mathrm{r}=0.771$, $\mathrm{p}=0.127$ ), with the number of gout patients in adult men (aged $\geq 20$ years $)$ in 2004-2016 ( $\mathrm{r}=0.805, \mathrm{p}=0.100)$, and with the number of gout patients in adult women (aged $\geq 20$ years) in 2004-2016 $(\mathrm{r}=-0.387, \mathrm{p}=0.519)$.

\subsubsection{Animal Fat}

The daily animal fat intake of Japanese people in 2016 was higher compared to that in 1972, 1975, 1980, 1986, 1989, 1992, 2001, 2004, 2007, 2010, and 2013 and was lower compared to that in 1995 and 1998 (1972: $27.0 \mathrm{~g} / \mathrm{day}$; 1975: 27.4 g/day; 1980: 26.9 g/day; 1986: 27.9 g/day; 1989: 28.3 g/day; 1992: 28.5 g/day; 1995: 29.8 g/day; 1998: 29.2 g/day; 2001: 27.2 g/day; 2004: 26.8 g/day; 2007: 27.7 g/day; 2010: $27.1 \mathrm{~g} /$ day; 2013: $28.1 \mathrm{~g} /$ day; 2016: $29.1 \mathrm{~g} /$ day).

The daily animal fat intake did not show a significant correlation with the number of gout patients in 1986-2016 (r= $-0.285, p=0.396$ ), with the number of gout patients in the adult population (aged $\geq 20$ years) in 2004-2016 ( $\mathrm{r}=0.848$, $\mathrm{p}=0.0692)$, and with the number of gout patients in adult men (aged $\geq 20$ years) in 2004-2016 $(\mathrm{r}=0.860, \mathrm{p}=0.0617)$, and with the number of gout patients in adult women (aged $\geq 20$ years) in 2004-2016 $(r=-0.426, p=0.474)$. This result suggests that the correlation of daily animal fat intake with the number of gout patients tends to vary with gender and is stronger in adult men than in adult women.

\subsubsection{Vegetable Fat}

The vegetable fat is from grains, potatoes, legumes, seeds, nuts, fruit, vegetables, mushrooms, and seaweed. The daily vegetable fat intake of Japanese people in 2016 was lower compared to that in 1986, 1989, 1992, 1995, and 1998 and was higher compared to that in 2007, 2010, and 2013 (1986: 28.7 g/day; 1989: 30.6 g/day; 1992: 29.9 g/day; 1995: 30.2 g/day; 1998: 28.7 g/day; 2007: 27.3 g/day; 2010: 26.7 g/day; 2013: $26.9 \mathrm{~g} /$ day; 2016: $28.1 \mathrm{~g} /$ day).

The daily intake of vegetable fat was negatively correlated with the number of gout patients in 1986-2016 $(r=-0.840$, $\mathrm{p}=0.00121$ ). The daily intake of vegetable fat did not show a significant correlation with the number of gout patients in the adult population (aged $\geq 20$ years) in 2004-2016 ( $\mathrm{r}=0.580$, $\mathrm{p}=0.306$ ), with the number of gout patients in adult men (aged $\geq 20$ years $)$ in 2004-2016 ( $\mathrm{r}=0.691, \mathrm{p}=0.197)$, and with the number of gout patients in adult women (aged $\geq 20$ years) in 2004-2016 $(\mathrm{r}=-0.240, \mathrm{p}=0.698)$.

\subsubsection{Saturated Fatty Acids}

The daily saturated fatty acids intake of Japanese in 2016 was lower compared to that in 1995, and 1998 and was higher compared to that in 2002, 2005, 2007, 2010, and 2013 (1995: $18.4 \mathrm{~g} /$ day; $1998: 17.7 \mathrm{~g} /$ day; 2002: $14.3 \mathrm{~g} /$ day; 2005: 14.8 g/day; 2007: 15.0 g/day; 2010: 14.7 g/day; 2013: 15.1 g/day; 2016: $15.7 \mathrm{~g} /$ day).

Though the daily saturated fatty acids intake was negatively correlated with the number of gout patients in 1995-2016 ( $\mathrm{r}=$ $-0.873, \mathrm{p}=0.0233$ ), Japanese adult men (aged 20-49 years) and women (aged $\geq 20$ years) should reduce the daily saturated fatty acids intake for the prevention of lifestyle-related diseases including gout.

The Japanese Society of Hypertension Guidelines for the Management of Hypertension [130] have recommended refraining from consuming saturated fatty acids and cholesterol for patients with hypertension. Some guidelines for the prevention of cardiovascular disease (CVD) have stated that reducing intakes of total fat (to less than $30 \%$ of total energy intake) and saturated fatty acids (to less than $10 \%$ of total energy intake) and replacement of saturated fatty acids with polyunsaturated fatty acids are likely to be beneficial for the prevention of CVD in healthy adults [106, 107]. The 2016 European Guidelines on cardiovascular disease prevention in clinical practice [106] has stated that trans unsaturated fatty acids intake should be as little as possible, with preferably no intake from processed food, and $<1 \%$ of total energy intake from natural origins for CVD prevention.

\subsubsection{The Mean Ratio of Energy Intake from Saturated Fatty Acids in Total Energy Intake (Saturated Fatty Acids/Energy)}

In Japanese men and women in 2016, the mean ratio of energy intake from saturated fatty acids in total energy intake (Saturated fatty acids/Energy) for men (aged 20-49 years) and 
women (aged $\geq 20$ years) was $7.21-7.83 \%$ of energy and $7.01-8.44 \%$ of energy, respectively, and exceeded the tentative dietary goal for preventing lifestyle-related diseases (DG) ( $\leq 7 \%$ of energy) [15]. In Japanese men and women in 2016 , the mean ratio of energy intake from saturated fatty acids in total energy intake (Saturated fatty acids/Energy) for men (aged $\geq 50$ years) was $6.50-6.97 \%$ of energy and was within the tentative dietary goal for preventing lifestyle-related diseases (DG) $(\leq 7 \%$ of energy) [15].

The mean ratio of energy intake from saturated fatty acids in total energy intake (Saturated fatty acids/Energy) did not show a significant correlation with the number of gout patients in 1995-2016 $(\mathrm{r}=-0.757, \mathrm{p}=0.0817)$, with the number of gout patients in the adult population (aged $\geq 20$ years) in 2007-2016 $(\mathrm{r}=0.889, \mathrm{p}=0.111)$, with the number of gout patients in adult men (aged $\geq 20$ years) in 2007-2016 $(r=0.922, p=0.0775)$, and with the number of gout patients in adult women (aged $\geq 20$ years $)$ in $2007-2016(r=0.452, p=0.548)$. This result suggests that the correlation of the mean ratio of energy intake from saturated fatty acids in total energy intake (Saturated fatty acids/Energy) with the number of gout patients tends to be stronger in adult men than in adult women.

\subsubsection{Polyunsaturated Fatty Acids}

The Ministry of Health, Labour and Welfare of Japan [15] has not set the tentative dietary goal for preventing lifestyle-related diseases (DG) for the daily intake of n-3 polyunsaturated fatty acids and n-6 polyunsaturated fatty acids in Japanese men and women.

1. $n-3$ polyunsaturated fatty acids

The daily n-3 polyunsaturated fatty acids intake of Japanese people in 2016 was less than that in 2007, 2010, and 2013 (2007: $2.37 \mathrm{~g} /$ day; 2010: $2.24 \mathrm{~g} /$ day; 2013: $2.17 \mathrm{~g} /$ day; 2016: $2.16 \mathrm{~g} /$ day). In Japanese men and women in 2016, the daily n-3 polyunsaturated fatty acids intake for men (aged 20-49 years and aged $\geq 60$ years) and women (aged $\geq 15$ years) was 2.27-2.35 g/day, 2.53-2.67 g/day, and 1.84-2.33 g/day, respectively, and exceeded the adequate intake (AI) [men (aged 20-49 years): $2.0 \mathrm{~g}$ /day; men (aged $\geq 60$ years): $2.1-2.2$ $\mathrm{g} /$ day; women (aged $\geq 15$ years): $1.6-2.0 \mathrm{~g} /$ day] [15]. This result suggests that the daily $n-3$ polyunsaturated fatty acids intake in Japanese men (aged 20-49 years and aged $\geq 60$ years) and women (aged $\geq 15$ years) appears to be very unlikely to cause a deficiency.

The daily $n-3$ polyunsaturated fatty acids intake was negatively correlated with the number of gout patients in 2007-2016 $(r=-0.975, p=0.0246)$. Diets enriched in both linolenic acid and eicosapentaenoic acid (EPA) significantly suppressed urate crystal-induced inflammation in a rat model [131]. These fatty acids show a potential protective role against gout flares.

Eating foods rich in n-3 polyunsaturated fatty acids is recommended to prevent or treat cardiovascular disease (CVD) [119]. Fatty fish contains rich in n-3 polyunsaturated fatty acids [eicosapentaenoic acid (EPA) and docosahexaenoic acid (DHA)]. Fish 1-2 times per week, one of which should be oily fish, is recommended for the prevention of CVD [106]. One should consume at least $250 \mathrm{mg} /$ day of long-chain $\mathrm{n}-3$ polyunsaturated fatty acids or at least 2 servings/week of oily fish [132]. Nuts and seeds contain rich in n-3 polyunsaturated fatty acids [alpha linolenic acid (ALA)]. It seems important for Japanese people to eat fatty fish, nuts, and seeds to take in more n-3 polyunsaturated fatty acids for the prevention of gout and CVD.

\section{2. $n-6$ polyunsaturated fatty acids}

The daily n-6 polyunsaturated fatty acids intake of Japanese people in 2016 was higher compared to that in 2007, 2010, and 2013 (2007: 9.45 g/day; 2010: 9.27 g/day; 2013: 9.28 g/day; 2016: $9.61 \mathrm{~g} /$ day). In Japanese men and women in 2016, the daily n-6 polyunsaturated fatty acids intake for men (aged $\geq 20$ years) and women (aged $\geq 20$ years) was 9.30-11.47 g/day and 8.15-9.45 g/day, respectively, and exceeded the adequate intake (AI) [men (aged $\geq 20$ years): 8.0-11.0 g/day; women (aged $\geq 20$ years): $7.0-8.0 \mathrm{~g} / \mathrm{day}$ ] [15]. This result suggests that the daily n-6 polyunsaturated fatty acids intake in Japanese men (aged $\geq 20$ years) and women (aged $\geq 20$ years) appears to be very unlikely to cause a deficiency.

The daily n-6 polyunsaturated fatty acids intake did not show a significant correlation with the number of gout patients in 2007-2016 ( $\mathrm{r}=0.221, \mathrm{p}=0.779)$.

\subsubsection{Cholesterol}

The Ministry of Health, Labour and Welfare of Japan [15] has not set an index for the daily intake of cholesterol in Japanese adults.

The daily cholesterol intake of Japanese people in 2016 was lower compared to that in 1995, 1998, 2001, 2004, and 2007 and was higher compared to that in 2010 and 2013 (1995: 383 $\mathrm{mg} /$ day; 1998: $370 \mathrm{mg} /$ day; 2001: $346 \mathrm{mg} /$ day; 2004: 320 $\mathrm{mg}$ /day; 2007: $323 \mathrm{mg} /$ day; 2010: $307 \mathrm{mg}$ /day; 2013: 307 $\mathrm{mg}$ /day; 2016: $311 \mathrm{mg} /$ day). In Japanese men and women in 2016 , the daily cholesterol intake for men (aged $\geq 1$ year) and women (aged $\geq 1$ year) was 206-431 mg/day and 200-351 $\mathrm{mg} /$ day, respectively. The Ministry of Health, Labour and Welfare in Japan [15] has stated that, for the daily cholesterol intake, it is desirable to take less than $200 \mathrm{mg}$ from the viewpoint of preventing aggravation of dyslipidemia. Thus, it is important for Japanese people to reduce daily cholesterol intake to prevent the aggravation of dyslipidemia.

The daily cholesterol intake did not show a significant correlation with the number of gout patients in the adult population (aged $\geq 20$ years) in 2004-2016 ( $\mathrm{r}=-0.609$, $\mathrm{p}=0.216$ ), with the number of gout patients in adult men (aged $\geq 20$ years $)$ in 2004-2016 $(\mathrm{r}=-0.610, \mathrm{p}=0.275)$, and with the number of gout patients in adult women (aged $\geq 20$ years) in 2004-2016 ( $\mathrm{r}=0.544, \mathrm{p}=0.343)$.

\subsubsection{The Mean Ratio of Energy Intake from Fat in Total Energy Intake (Fat/Energy)}

The mean ratio of energy intake from fat in total energy intake (Fat/Energy) in 1986, 1989, 1992, 1995, 1998, 2001, 2004, 2007, 2010, 2013, and 2016 were $24.5-27.4 \%$ of energy. The mean ratio of energy intake from fat in total energy intake (Fat/Energy) in 2016 was higher compared to that in 1975, 1980, 1986, 1989, 1992, 1995, 1998, 2001, 2004, 2007, 2010, 
and 2013 (1975: 22.3\%; 1980: 23.6\%; 1986: 24.5\%; 1989: $25.7 \%$; 1992: $25.5 \%$; 1995: 26.2\%; 1998: 26.1\%; 2001: $25.2 \%$; 2004: 25.3\%; 2007: 25.8\%; 2010: $25.9 \%$; 2013: 26.2\%; 2016: 27.4\%). In Japanese men and women in 2016, the mean ratio of energy intake from fat in total energy intake (Fat/Energy) of Japanese men (aged $\geq 1$ year) and women (aged 1-14 years and $\geq 30$ years) in 2016 was $24.3-28.8 \%$ of energy, $27.6-29.4 \%$ of energy, and $25.6-29.4 \%$ of energy, respectively, and was within the tentative dietary goal for preventing lifestyle-related diseases (DG) [men (aged $\geq 1$ year): $20-30 \%$ of energy; women (aged $\geq 1$ year): $20-30 \%$ of energy] [15]. In Japanese men and women in 2016, the mean ratio of energy intake from fat in total energy intake (Fat/Energy) for women (15-29 years) exceeded the tentative dietary goal for preventing lifestyle-related diseases (DG)(30.1-30.8\% of energy) [15].

The mean ratio of energy intake from fat in total energy intake (Fat/Energy) did not show a significant correlation with the number of gout patients in 1986-2016 $(\mathrm{r}=0.514, \mathrm{p}=0.106)$. The mean ratio of energy intake from fat in total energy intake (Fat/Energy) was positively correlated with the number of gout patients in the adult population (aged $\geq 20$ years) in 2004-2016 ( $\mathrm{r}=0.856, \mathrm{p}=0.0453$ ), and with the number of gout patients in adult men (aged $\geq 20$ years) in 2004-2016 ( $\mathrm{r}=0.924$, $\mathrm{p}=0.0247$ ). The mean ratio of energy intake from fat in total energy intake (Fat/Energy) did not show a significant correlation with the number of gout patients in adult women (aged $\geq 20$ years) in 2004-2016 $(\mathrm{r}=-0.677, \mathrm{p}=0.209)$. This result suggests that the correlation of the mean ratio of energy intake from fat in total energy intake (Fat/Energy) with the number of gout patients varies with gender and is stronger in adult men than in adult women.

In epidemiological studies, increased intake of fat was associated with increased SUA concentrations [54]. The ideal balance of the caloric ratio of protein, fat, and carbohydrate for healthy life is protein: $15 \%$, fat: $25 \%$, and carbohydrates: $60 \%$ [120]. It seems better to decrease the mean ratio of energy intake from fat in total energy intake (Fat/Energy) until 25\%. Especially decrease in the daily saturated fatty acids intake for Japanese adult men (aged 20-49 years) and women (aged $\geq 20$ years) is important.

\subsection{Caloric Ratio of Protein, Fat, and Carbohydrate}

The balance of the caloric ratio of protein, fat, and carbohydrate in Japanese people in 1965 was protein: 13.1\%, fat: $14.8 \%$, and carbohydrates: $70.3 \%$ [120]. The balance of the caloric ratio of protein, fat, and carbohydrate in Japanese people in 1975 was near the ideal balance for healthy life (protein: 14.6\%, fat: $21.4 \%$, and carbohydrates: $61.6 \%$ )[120]. Compared to the Japanese diet in 1965, in the Japanese diet in 1975-2016, the mean ratio of energy intake from protein in total energy intake (Protein/Energy) and the mean ratio of energy intake from fat in total energy intake (Fat/Energy) increased and the mean ratio of energy intake from carbohydrate in total energy intake (Carbohydrate /Energy) decreased.

Compared to the Japanese diet in 2010, in the Japanese diet in 2016 , the mean ratio of energy intake from protein in total energy intake (Protein/Energy) and the mean ratio of energy intake from fat in total energy intake (Fat/Energy) increased by $0.7 \%$ and $5.8 \%$, respectively and the mean ratio of energy intake from carbohydrate in total energy intake (Carbohydrate /Energy) decreased by $2.7 \%$. The balance of the caloric ratio of protein, fat, and carbohydrate in Japanese people in 2016 was weighted toward fat (protein: $14.8 \%$, fat: $27.4 \%$, and carbohydrates: $57.8 \%$ ). Japanese people need to decrease fat (especially saturated fatty acids) intake.

Table 1. Correlation between number of gout patients and macronutrient intake in Japanese people in 1986-2016.

\begin{tabular}{lll}
\hline Macronutrient & coefficient & p-value \\
\hline Energy & -0.984 & 0.0000000514 \\
Carbohydrate & -0.978 & 0.00000215 \\
Dietary Fiber* & -0.946 & 0.000036 \\
Carbohydrate/Energy & -0.058 & 0.865 \\
Total Protein** & -0.937 & 0.0000215 \\
Animal Protein & -0.823 & 0.00185 \\
Vegetable Protein & -0.974 & 0.000000417 \\
Protein/Energy & -0.697 & 0.0172 \\
Total Fat & -0.677 & 0.0221 \\
Animal Fat & -0.285 & 0.396 \\
Vegetable Fat & -0.840 & 0.00121 \\
Fat/Energy & 0.514 & 0.106 \\
\hline
\end{tabular}

*The daily dietary fiber intake of Japanese people (aged $\geq 15$ years) in 2016 was below the tentative dietary goal for preventing lifestyle-related diseases (DG). **The daily total protein intake for Japanese people (aged $\geq 1$ year) exceeded the recommended dietary allowance (RDA). Abbreviation: Carbohydrate/Energy, The mean ratio of energy intake from carbohydrate in total energy intake; Protein/Energy, The mean ratio of energy intake from protein in total energy intake; Fat/Energy, The mean ratio of energy intake from fat in total energy intake.

\subsection{Water Intake}

The mean total water intake of Japanese adults (aged 30-76 years), Japanese men (aged 30-76 years), Japanese women (aged 30-69 years) was $2230 \mathrm{~g} / \mathrm{day}, 2423 \mathrm{~g} /$ day, and 2037 $\mathrm{g} /$ day, respectively [133]. Since there is only this report on water intake of Japanese people, the Ministry of Health, Labour and Welfare in Japan [15] has not established the adequate intake (AI) for water intake of Japanese people.

Consumption of water to maintain hydration was associated with decreased risk of gout flares in an internet-based case-crossover study [134]. Specifically, consumption of five to eight glasses $(250 \mathrm{~mL}$ each) of water in a 24 -hour period or drinking more than eight glasses of water in a 24-hour period was associated with decreased risk of gout flares [134]. Therefore, Terkeltaub and Edwards [135] have stated that the gout patient can help lessen gout flares by moderating food portion sizes and content, by not drinking alcohol in excess in short time periods, and by staying well hydrated (five or eight $250-\mathrm{mL}$ servings of water daily unless medically contraindicated).

The guidelines have stated importance of fluid intake for management in patients with gout [7, 51], urolithiasis [118], diabetes mellitus [119]. Japanese Urological Association., Japanese Society of Endourology., Japanese Society on Urolithiasis Research [136] has recommended that fluid amount is more than $2.0 \mathrm{~L} /$ day for patients with urolithiasis. 


\section{Limitation}

Jakše et al. [137] have stated that a patient's individual risk likely represents a complex interplay between nonmodifiable factors (e.g., age, gender, race, and genetics) and modifiable factors (e.g., diet, body weight, and lifestyle). Lifestyle-related diseases including gout are not caused or prevented by a single nutrient, but they involve environmental and genetic factors. The number of patients with gout estimated from the Comprehensive Survey of Living Conditions was based on self-reporting by residents. In the National Health and Nutrition Survey performed by the Ministry of Health, Labour and Welfare in Japan, the daily intake of nutrients, etc. was calculated using the Standard Tables of Food Composition in Japan prepared by the Ministry of Education, Culture, Sports, Science and Technology in Japan. Regarding the method of quantifying nutrients contained in food, it is unavoidable that there will be discrepancies in the calculated values depending on which ingredient table is used. The Standard Tables of Food Composition in Japan are revised every five years. It is necessary to consider that the content of nutrients in foods reported in the Standard Tables of Food Composition in Japan fluctuates because the analysis method is different or is improved due to technological progress. It must be also taken into account that the content of nutrients in foods differ from the cooked meals that the person actually consumes.

\section{Conclusion}

The phenomenon that the number of gout patients has increased with the westernization of the Japanese diet since 1955 was described in the previous report [13]. This article showed the relationship between the number of gout patients and macronutrient intake in Japanese people and suggested modification of macronutrient intake for the prevention of gout in Japanese people referencing the results of clinical research. Modification of macronutrient intake for the prevention of gout in Japanese people (especially adults) is suggested as follows: energy-providing nutrient balance (percentages of proteins, fats, and carbohydrates in total energy intake) should be within the range of the tentative dietary goal for preventing lifestyle-related diseases (DG); reduce fat (especially animal fat) intake and maintain the mean ratio of energy intake from saturated fatty acids in total energy intake (Saturated fatty acids/Energy) within the range of the tentative dietary goal for preventing lifestyle-related diseases (DG); limiting or decreasing intake of fat (especially animal fat); replacement of saturated fatty acids (e.g., dairy fats, meat fat) with mono- and polyunsaturated fatty acids (especially n-3 polyunsaturated fatty acids) (e.g., macadamia nuts, almonds, peanuts and peanut butter, olive oil, canola oil, avocados); avoidance of excessive intake of saturated fatty acids and cholesterol; pay attention to sucrose and fructose intake; increase intake of dietary fiber; and maintenance of good hydration. It is necessary to recognize how much micronutrient (vitamin and mineral) intake and alcohol consumption is important as potential dietary habits to prevent gout in Japanese people.

\section{Conflict of Interest Statement}

The author declares that there are no conflicts of interest.

\section{Acknowledgements}

The author thanks Prof. Eiko Ota (Kokugakuin University Tochigi Junior College), Ms. Yuko Itabashi, Ms. Tamae Yanagita, Ms. Nao Uzuka, and Ms. Yumi Kuwabara for furnishing references at Kokugakuin University Tochigi Gakuen Library.

\section{References}

[1] The Ministry of Health, Labour and Welfare. Household Statistics Office. (2020) Comprehensive Survey of Living Conditions [Internet]. Available from: https://www.mhlw.go.jp/toukei/list/20-21kekka.html.

[2] Mikanagi, K. (1963) Gout in Japan. The Kyosai Medical Journal, 12, 14-37 (in Japanese).

[3] Kawasaki, T., \& Shichikawa, K. (2006) Epidemiological survey of gout by resident examination. Gout and nucleic acid metabolism, 30, 66 .

[4] Oshima, Y. (1965) Clinical studies on Japanese gout. J Jpn Soc Int Med, 54, 291-310 (in Japanese).

[5] Hakoda, M., \& Kasagi, F. (2018) Trends in gout and hyperuricemia in Japan. Gout and nucleic acid metabolism, 42, 110 (in Japanese).

[6] Nishioka, K., Mikanagi, K., \& Hirose, K. (1974) Clinical study of gout and hyperuricemia: Epidemiology and pathogenesis. Rheum, 14, 95-105.

[7] Hisatome, I., Ichida, K., Mineo, I., Ohtahara, A., Ogino, K., Kuwabara, M., Ishizaka, N., Uchida, S., Kurajoh, M., Kohagura, K., Sato, Y., Taniguchi, A., Tsuchihashi, T., Terai, C., Nakamura, T., Hamaguchi, T., Hamada, T., Fujimori, S., Masuda, I., Moriwaki, Y., Yamamoto, T. on behalf of guideline development group. (2018) Japanese Society of Gout and Uric \& Nucleic Acids Guidelines for Management of Hyperuricemia and Gout: 3 rd edition. SHINDAN TO CHIRYO SHA, Inc. pp. 1-169. Tokyo (in Japanese).

[8] Nishioka, K., \& Mikanagi, K. (1980) Hereditary and environmental factors influencing on the serum uric acid throughout ten years population study in Japan. Adv Exp Med Biol, 122A, 155-159.

[9] Smith, E., Hoy, D., Cross, M., Merriman, T. R., Vos, T., Buchbinder, R., Woolf, A., \& March, L. (2014) The global burden of gout: estimates from the Global Burden of Disease 2010 study. Ann Rheum Dis, 73, 1470-1476.

[10] Castro, K. E., Corey, K. D., Raymond, D. L., Jiroutek, M. R., \& Holland, M. A. (2018) An evaluation of gout visits in the United States for the years 2007 to 2011. BMC Rheumatology, 2, 14.

[11] Akizuki, S. (1982) A population study of hyperuricemia and gout in Japan: analysis of sex, age and occupational differences in thirty-four thousand people living in Nagano prefecture. Ryumachi, 22, 201-208 (in Japanese). 
[12] The Ministry of Health, Labour and Welfare. Health Service Bureau. (2020) National Health and Nutrition Survey Japan, 1946-2017 [Internet]. Available from: https://www.mhlw.go.jp/bunya/kenkou/kenkou_eiyou_chousa. html.

[13] Koguchi, T. (2021) Modification of dietary habits for prevention of gout in Japanese people: Gout and the Japanese diet. Am J Health Res. (in press).

[14] Hakoda, M, \& Kasagi, F. (2020) Future trends for the number of gout patients in Japan. Gout and Uric \& Nucleic Acids, 44, 33-39.

[15] The Ministry of Health, Labour and Welfare, Japan. (2020) Dietary Reference Intakes for Japanese, 2020 [Internet]. Available from: https://www.mhlw.go.jp/file/06-Seisakujouhou-10900000-Ken koukyoku/Overview.pdf.

[16] National Institute of Health and Nutrition [Internet]. Available from:

www.nibiohn.go.jp/eiken/kenkounippon21/eiyouchousa/keine n_henka_time.html.

[17] The Council for Science and Technology, Ministry of Education, Culture, Sports, Science and Technology in Japan. (2020) Standard tables of food composition in Japan -2020(Eighth Revised Edition), Report of the Subdivision Resources [Internet]. Available from: https://www.mext.go.jp/content/20201225-mxt_kagsei-mext_ 01110_011.pdf.

[18] U.S. Department of Health \& Human Services. National Institutes of Health. Office of Dietary Supplements. Dietary Supplement Fact Sheets [Internet]. Available from: Dietary Supplement Fact Sheets (nih.gov).

[19] Araki, E., Goto, A., Kondo, T., Noda, M., Noto, H., Origasa, H., Osawa, H., Taguchi, A., Tanizawa, Y., Tobe, K., \& Yoshioka, N. (2020) Japanese clinical practice guideline for diabetes 2019. Diabetology International, 11, 165-223.

[20] Ikizler, T. A., Burrowes, J. D., Byham-Gray, L. D., Campbell, K. L., Carrero, J-J., Chan, W., Fouque, D., Friedman, A. N., Ghaddar, S., Goldstein-Fuchs, D. J., Kaysen, G. A., Kopple, J. D., Teta, D., Wang, A. Y-M., \& Cuppari, L. (2020) KDOQI clinical practice guideline for nutrition in CKD: 2020 update. Am J Kidney Dis, 76, S1-S107.

[21] Koguchi, T. (2018) Essentials of dietary habits for prevention and suppression of hyperuricemia. Curr Top Pharmacol, 22, 77-133.

[22] Marriott, B. P., Cole, N., \& Lee, E. (2009) National estimates of dietary fructose intake increased from 1977 to 2004 in the United States. J Nutr, 139 (Suppl), 1228S-1235S.

[23] Wang, D. D., Sievenpiper, J. L., de Souza, R. J., Chiavaroli, L., Ha, V., Cozma, A. I., Mirrahimi, A., Yu, M. E., Carleton, A. J., Buono, M. D., Jenkins, A. L., Leiter, L. A., Wolever, T. M. S., Beyene, J., Kendall, C. W. C., \& Jenkins, D. J. A. (2012) The effects of fructose intake on serum uric acid vary among controlled dietary trials. J Nutr, 142, 916-923.

[24] Emmerson, B. T. (1974) Effect of oral fructose on urate production. Ann Rheum Dis, 33. 276-280.

[25] Fox, I. H., \& Kelley, W. N. (1972) Studies on the mechanism of fructose-induced hyperuricemia in man. Metabolism, 21, 713-721.

[26] Raivio, K. O., Becker, A., Meyer, L. J., Greene, M. L., Nuki, G., \& Seegmiller, J. E. (1975) Stimulation of human purine synthesis de novo by fructose infusion. Metabolism, 24, 861-869.

[27] Karczmar, G. S., Kurtz, T., Tavares, N. J., \& Weiner, M. W. (1989) Regulation of hepatic inorganic phosphate and ATP in response to fructose loading.; A in vivo 31P-NMR study. Biochim Biophys Acta, 1012, 121-127.

[28] DeBosch, B. J., Chen, Z., Finck, B. N., Chi, M., \& Moley, K. H. (2013) Glucose transporter-8 (GLUT8) mediates glucose intolerance and dyslipidemia in high-fructose diet-fed male mice. Mol Endocrinol, 27, 1887-1896.

[29] Gibson, T., Rodgers, A. V., Simmonds, H. A., Court-Brown, F., Todd, E., \& Meilton, V. (1983) A controlled study of diet in patients with gout. Ann Rheum Dis, 42, 123-127.

[30] Sahebjami, H., \& Scalettar, R. (1971) Effects of fructose infusion on lactate and uric acid metabolism. Lancet, 297, 366-369.

[31] Le, M. T., Shafiu, M., Mu, W., \& Johnson, R. J. (2008) SLC2A9-a fructose transporter identified as a novel uric acid transporter. Nephrol Dial Transplant., 23, 2746-2749.

[32] Caliceti, C., Calabria, D., Roda, A., \& Cicero, A. (2017) Fructose intake, serum uric acid, and cardiometabolic disorders: A critical review. Nutrients, 9, 395.

[33] Choi, J. W. J., Ford, E. S., Gao, X., \& Choi, H. K. (2008) Sugar-sweetened soft drinks, diet soft drinks, and serum uric acid level: The third national health and nutrition examination survey. Arthritis. Rheum, 59, 109-116.

[34] Zhang, Z., Harman, J. L., Coresh, J., Köttgen, A., McAdams-DeMarco, M. A., Correa, A., Young, B. A., Katz, R., \& Rebholz, C. M. (2018) The dietary fructose: vitamin C intake ratio is associated with hyperuricemia in African-American adults. J Nutr, 148, 419-426.

[35] Li, R., Yu, K., \& Li, C. (2018) Dietary factors and risk of gout and hyperuricemia: a meta-analysis and systematic review. Asia Pac J Clin Nutr, 27, 1344-1356.

[36] Doherty, M. (2009) New insights into epidemiology of gout. Rheumatology (Oxford), 48 (suppl 2), ii2-ii8.

[37] Choi, H. K., \& Curhan, G. (2008) Soft drinks, fructose consumption, and the risk of gout in men; Prospective cohort study. BMJ, 336, 309-312.

[38] Choi, H. K., Willett, W., \& Curhan, G. (2010) Fructose-rich beverages and the risk of gout in women. JAMA, 304, 2270-2278.

[39] Jamnik, J., Rehman, S., Mejia, S. B., de Souza, R. J., Khan, T. A., Leiter, L. A., Wolever, T. M. S., Kendall, C. W. C. Jenkins, D. J. A., \& Sievernpiper, J. L. (2016) Fructose intake and risk of gout and hyperuricemia: a systematic review and meta-analysis of prospective cohort studies. BMJ Open, 6, e013191.

[40] Xia, Y., Wu, Q., Wang, H., Zhang, S., Jiang, Y., Gong, T., Xu, X., Chang, Q., Niu, K., \& Zhao, Y. (2020) Global, regional and national burden of gout:, 1990-2017: a systematic analysis of the Global Burden of Disease Study. Rheumatology (Oxford), 59, 1529-1538.

[41] Chuang, S. Y., Lee, S. C., Hsieh, Y. T., \& Pan, W. H. (2011) Trends in hyperuricemia and gout prevalence: Nutrition and Health Survey in Taiwan from 1993-1996 to 2005-2008. Asia Pac J Clin Nutr, 20, 301-308.

[42] Merriman, T. R., Dalbeth, N., \& Johnson, R. J. (2014) Sugar-sweetened beverages, urate, gout and genetic interaction. Pac Health Dialog, 20, 31-38. 
[43] Kontogianni, M. D., Chrysohoou, C., Panagiotakos, D. B., Tsetsekou, E., Zeimbekis, A., Pitsavos, C., \& Stefanadis, C. (2012) Adherence to the Mediterranean diet and serum uric acid: the ATTICA study. Scand J Rheumatol, 41, 442-449.

[44] Zgaga, L., Theodoratou, E., Kyle, J., Farrington, S. M., Agakov, F., Tenesa, A., Walker, M., McNeill, G., Wright, A. F., Rudan, I., Dunlop, M. G., \& Campbell, H. (2012) The association of dietary intake of purine-rich vegetables, sugar-sweetened beverages and dairy with plasma urate, in a cross-sectional study. PLoS One, 7, e38123.

[45] Nguyen, S., Choi, H. K., Lustig, R. H., \& Hsu, C. Y. (2009) Sugar-sweetened beverages, serum uric acid, and blood pressure in adolescents. J Pediatr, 154, 807-813.

[46] Stanhope, K. L. (2016) Sugar consumption, metabolic disease and obesity: The state of the controversy. Crit Rev Clin Lab Sci, $53,52-67$.

[47] FitzGerald, J. D., Dalbeth, N., Mikuls, T., Brignardello-Petersen, R., Guyatt, G., Abeles, A. M., Gelber, A. C., Harrold, L. R., Khanna, D., King, C., Levy, G., Libbey, C., Mount, D., Pillinger, M. H., Rosenthal, A., Singh, J. A., Sims, J. E., Smith, B. J., Wenger, N. S., Bae, S. S., Danve, A., Khanna, P. P., Kim, S. C., Lenert, A., Poon, S., Qasim, A., Sehra, S. T., Sharma, T. S. K., Toprover, M., Turgunbaev, M., Zeng, L., Zhang, M. A., Turner, A. S., \& Neogi, T.(2020) 2020 American College of Rheumatology guideline for the management of gout. Arthritis Care Research, 72, 744-760.

[48] Kobayashi, T., Inokuchi, T., Yamamoto, A., Takahashi, S., Ka, T., Tsutsumi, Z., Saito, H., Moriwaki, Y., \& Yamamoto, T. (2007) Effects of sucrose on plasma concentrations and urinary excretion of purine bases. Metabolism, 56, 439-443.

[49] Beydoun, M. A., Fanelli-Kuczmarski, M. T., Canas, J-A., Beydoun, H. A., Evans, M. K., \& Zonderman, A. B. (2018) Dietary factors are associated with serum uric acid trajectory differentially by race among urban adults. Br J Nutr, 120, 935-945.

[50] Tappy, L., Morio, B., Azzout-Mamiche, D., Champ, M., Gerber, M., Houdart, S., Mas, E., Rizkalia, S., Slama, G., Mariotti, F., \& Margaritis, I. (2018) French recommendations for sugar intake in adults: a novel approach chosen by ANSES. Nutrients, 10,989 .

[51] Khanna, D., Fitzgerald, J. D., Khanna, P. P., Bae, S., Singh, M. K., Neogi, T., Pillinger, M. H., Merill, J., Lee, S., Prakash, S., Kaldas, M., Gogia, M., Perez-Ruiz, F., Taylor, W., Lioté, F., Choi, H., Singh, J. A., Dalbeth, N., Kaplan, S., Niyyar, V., Jones, D., Yarows, S. A., Roessler, B., Kerr, G., King, C., Levy, G., Furst, D. E., Edwards, N. L., Mandell, B., Schumacher, H. R., Robbins, M., Wenger, N., \& Terkeltaub, R. (2012) 2012 American College of Rheumatology guidelines for management of gout. Part 1: systematic nonpharmacologic and pharmacologic therapeutic approaches to hyperuricemia. Arthritis Care Research, 64, 1431-1446.

[52] Carabin, I. G., Lyon, M. R., Wood, S., Pelletier, X., Donazzolo, Y., \& Burdock, G. A. (2009) Supplementation of the diet with the functional fiber PolyGlycoplex is well tolerated by healthy subjects in a clinical trial. Nutr J, 8, 9.

[53] Yamaguchi, Y., Ando, C., Tsukamoto, S., Nagao, J., Ueda, T., Yamaguchi, H., \& Akaoka, I. (2007) The effect on the serum uric acid level of long-term intake of chitosan-supplemented food and its safety in adults. J Jpn Soc Clin Nutr, 29, 104-113 (in Japanese).
[54] Zykova, S. N., Storhaug, H. M., Toft, I., Chadban, S. J., Jenssen, T. G., \& White, S. L. (2015) Cross-sectional analysis of nutrition and serum uric acid in two Caucasian cohorts: the AusDiab Study and the Tromsø study. Nutr J, 14, 49.

[55] Sun, S. Z., Flickinger, B. D., Williamson-Hughes, P. S., \& Empie, M. W. (2010) Lack of association between dietary fructose and hyperuricemia risk in adults. Nutr Metab (Lond), 7, 16.

[56] So, M. W., Lim, D-H., Kim, S-H., \& Lee, S. (2020) Dietary and nutritional factors associated with hyperuricemia: The seventh Korean National Health and Nutrition Examination Survey. Asia Pac J Clin Nutr, 29, 609-617.

[57] Shatat, I. F., Abdallah, R. T., Sas, D. J., \& Hailpern, S. M. (2012) Serum uric acid in US adolescents: distribution and relationship to demographic characteristics and cardiovascular risk factors. Pediatric Research, 72, 95-100.

[58] Yu, K-H., See, L-C., Huang, Y-C., Yang, C-H., \& Sun, J-H. (2008) Dietary factors associated with hyperuricemia in adults. Semin Arthritis Rheum, 37, 243-250.

[59] Sun, Y., Sun, J., Zhang, P., Zhong, F., Cai, J., \& Ma, A. (2019) Association of dietary fiber intake with hyperuricemia in U.S. adults. Food Funct, 10, 4932-4940.

[60] Lyu, L. C., Hsu, C. Y., Yeh, C. Y., Lee, M. S., Huang, S. H., \& Chen, C. L. (2003) A case-control study of the association of diet and obesity with gout in Taiwan. Am J Clin Nutr, 78, 690-701.

[61] Vieira, A. T., Galväo, I., Macia, L. M., Sernaglia, É. M., Vinolo, M. A., Garcia, C. C., Tavares, L. P., Amaral, F. A., Sousa, L. P., Martins, F. S., Mackay, C. R., \& Teixeira, M. M. (2017) Dietary fiber and the short-chain fatty acid acetate promote resolution of neutrophilic inflammation in a model of gout in mice. J Leukoc Biol, 101, 275-284.

[62] Lin, Z., Zhang, B., Liu, X., Jin, R., \& Zhu, W. (2014) Effects of chicory inulin on serum metabolites of uric acid, lipids, glucose, and abdominal fat deposition in quails induced by purine-rich diets. J Med Food, 17, 1214-1221.

[63] Guo, Y., Yu, Y., Li, H., Ding, X., Li, X., Jing, X., Chen, J., Liu, G., Lin, Y., Jiang, C., Liu, Z., He, Y., Li, C., \& Tian, Z. (2020) Inulin supplementation ameliorates hyperuricemia and modulates gut microbiota in Uox-knockout mice. Eur J Nutr [Internet]. Available from: https://doi.org/10.1007/s00394-020-02414-x.

[64] Zhang, Y., Shuai, T. G., Wu, C. M., Shen, J. J., \& Zhong, G. (2016) Effect of konjac glucomannan on hyperuricemic rats. Research \& Reviews: Journal of Food and Dairy Technology, 4, $18-25$.

[65] Zhang, Y., Deng, L., Wu, C. M., Zheng, L., \& Zhong, G. (2018) Konjac glucomannan improves hyperuricemia through regulating xanthine oxidase, adenosine deaminase and urate transporters in rats. Journal of Functional Foods, 48, 566-575.

[66] Koguchi, T., Wada, M., Ota, T., Nakajima, H., Tadokoro, T., \& Maekawa, A. (1997) Effect of dietary fiber on the amount of purine metabolites in the serum and urine of rats. J Agric Sci Tokyo Nogyo Daigaku (Tokyo University of Agriculture), 42, 163-172.

[67] Koguchi, T., Nakajima, H., Wada, M., Yamamoto, Y., Innami, S., Maekawa, A., \& Tadokoro, T. (2002) Dietary fiber suppresses elevations of uric acid and allantoin in serum and urine induced by dietary RNA and increases its excretion to feces in rats. J Nutr Sci Vitaminol, 48, 184-193. 
[68] Koguchi, T., Nakajima, H., Koguchi, H., Wada, M., Yamamoto, Y., Innami, S., Maekawa, A., \& Tadokoro, T. (2003) Suppressive effect of viscous dietary fiber on elevations of uric acid in serum and urine induced by dietary RNA in rats is associated with strength of viscosity. Int J Vitam Nutr Res, 73, 369-376.

[69] Koguchi, T., Koguchi, H., Nakajima, H., Takano, S., Yamamoto, Y., Innami, S., Maekawa, A., \& Tadokoro, T. (2004) Dietary fiber suppresses elevation of uric acid and urea nitrogen concentrations in serum of rats with renal dysfunction induced by dietary adenine. Int J Vitam Nutr Res, 74, 253-263.

[70] Koguchi, T., Koguchi, H., Nakajima, H., Takano, S., Yamamoto, Y., Innami, S., Maekawa, A., \& Tadokoro, T. (2004) Suppressive effect of dietary fiber on elevation of serum uric acid concentration induced by dietary adenosine and adenosine-5' -monophosphate in rats. J Jpn Assoc Dietary Fiber Res, 8, 83-91.

[71] Koguchi, T., Koguchi, H., Nakajima, H., Takano, S., Kobayashi, K-I., Yamamoto, Y., Wada, M., Innami, S., Maekawa, A., \& Tadokoro, T. (2008) Blood glucose and serum uric acid concentrations in streptozotocin-induced diabetic rats fed dietary RNA vary with type of dietary fiber. J Jpn Assoc Dietary Fiber Res, 12, 67-80.

[72] Koguchi, T., Nakajima, H., Takano, S., Ota, T., Wada, M., Innami, S., \& Tadokoro, T. (2016) Suppressive effect of agarose and cellulose on hyperuricemia induced by dietary RNA in rats. Curr Top Pharmacol, 20, 57-66.

[73] Koguchi, T., Nakajima, H., Takano, S., Ota, T., Wada, M., Innami, S., \& Tadokoro, T. (2018) Suppressive effect of carboxymethyl-chitin and chitin on hyperuricemia induced by dietary RNA in rats. Chitin and Chitosan Research, 24, 11-22 (in Japanese).

[74] Hosomi, A., Nakanishi, T., Fujita, T., Tamai, I., \& Hosomi, A (2012) Extra-renal elimination of uric acid via intestinal efflux transporter BCRP/ABCG2. PLoS ONE, 7, e30456.

[75] Nieuwdorp, M., Gilijamse, P. W., Pai, N., \& Kaplan, L. M. (2014) Role of the microbiome in energy regulation and metabolism. Gastroenterology, 146, 1525-1533.

[76] Hamer, H. M., Jonkers, D. M., Bast, A., Vanhoutvin, S. A., Fischer, M. A., Kodde, A., Troost, F., Venema, K., \& Brummer, R-J. M. (2009) Butyrate modulates oxidative stress in the colonic mucosa of healthy humans. Clin Nutr, 28, 88-93.

[77] Krishnamurthy, V. M. R., Wei, G., Baird, B. C., Murtaugh, M., Chonchol, M. B., Raphael, K. L., Greene, T., \& Beddhu, S. (2012) High dietary fiber intake associated with decreased inflammation and all-cause mortality in patients with chronic kidney disease. Kidney Int, 81, 300-306.

[78] Ajani, U. A., Ford, E. S., \& Mokdad, A. H. (2004) Dietary fiber and C-reactive protein: findings from national health and nutrition examination survey data. J Nutr, 134, 1181-1185.

[79] Ma, Y. S., Griffith, J. A., Chasan-Taber, L., Olendzki, B. C., Jackson, E., Stanek, E. J., Li, W. J., Pagoto, S. L., Hafner, A. R., \& Ockene, I. S. (2006) Association between dietary fiber and serum C-reactive protein. Am J Clin Nutr, 83, 760-766.

[80] Harms, L. M., Scalbert, A., Zamora-Ros, R., Rinaldi, S., Jenab, M., Murphy, N., Achaintre, D., Tjønneland, A., Olsen, A., Overvad, K., Mancini, F. R., Mahamat-Saleh, Y., Boutron-Ruault, M-C., Kühn, T., Katzke, V., Trichopoulou, A., Martimianaki G., Karakatsani, A., Palli, D., Panico, S., Sieri, S.,
Tumino, R., Sacerdote, C., Bueno-de-Mesquita, B., Vermeulen, R. C. H., Weiderpass, E., Nøst, T. H., Lasheras, C., Rodríguez-Barranco, M., Huerta, J. M., Barricarte, A., Dorronsoro, M., Hultdin, J., Schmidt, J. A., Gunter, M., Riboli, E., \& Aleksandrova, K. (2020) Plasma polyphenols associated with lower high-sensitivity C-reactive protein concentrations: a cross-sectional study within the European Prospective Investigation into Cancer and Nutrition (EPIC) cohort. Br J Nutr, 123, 198-208.

[81] Kantor, E. D., Lampe, J. W., Kratz, M., \& White, E. (2013) Lifestyle factors and inflammation: Associations by body mass index. PLoS One, 8, e67833.

[82] Ma, Y., Hébert, J. R., Li, W., Bertone-Johnson, E. R., Olendzki, B., Pagoto, S. L., Tinker, L., Rosal, M. C., Ockene, I. S., Ockene, J. K., Griffith, J. A., \& Liu, S. (2008) Association between dietary fiber and markers of systemic inflammation in the Women's Health Initiative Observational Study. Nutrition, 24, 941-949.

[83] Lattimer, J. M., \& Haub, M. D. (2010) Effects of dietary fiber and its components on metabolic health. Nutrients, 2, 1266-1289.

[84] Schariau, D., Borowicki, A, Habermann, N., Hofmann, T., Klenow, S., Miene, C., Munjal, U., Stein, K., \& Glei, M. (2009) Mechanisms of primary cancer prevention by butyrate and other products formed during gut flora-mediated fermentation of dietary fiber. Mutat Res, 582, 39-53.

[85] Ando, A., Bamba, T., \& Sasaki, M (1999) Physiological and anti-inflammatory roles of dietary fiber and butyrate in intestinal functions. JPEN J Parenter Enteral Nutr, 23, S70-S73.

[86] Hijova E., Szabadosova, V., Štofilová, J., \& Hrčková, G. (2013) Chemopreventive and metabolic effects of inulin on colon cancer development. J Vet Sci, 14, 387-393.

[87] Saura-Calixto, F. (2011) Dietary fiber as a carrier of dietary antioxidants: an essential physiological function. J Agric Food Chem, 59. 43-49.

[88] Pérez-Jiménez, J., Serrano, J., Tabernero, M., Arranz, S., Díaz-Rubio, M. E., García-Diz, L., Goñi, I., \& Saura-Calixto, F. (2009) Bioavailability of phenolic antioxidants associated with dietary fiber: plasma antioxidant capacity after acute and long-term intake in humans. Plant Food Hum Nutr, 64, 102-107.

[89] Palafox-Carlos, H., Ayala-Zavala, F. J., \& González-Aguilar, G. A. (2011) The role of dietary fiber in the bioaccessibility and bioavailability of fruit and vegetable antioxidants. J Food Sci, 76, R6-R15.

[90] Ríos-Hoyo, A., Cortés, M. J., Ríos-Ontiveros, H., Meaney, E., Ceballos, G., \& Gutiérrez-Salmeán, G. (2014) Obesity, metabolic syndrome, and dietary therapeutical approaches with a special focus on nutraceuticals (polyphenols): a mini-review. Int J Vitam Nutr Res, 84, 113-123.

[91] Vendrame, S., \& Klimis-Zacas, D. (2015) Anti-inflammatory effect of anthocyanins via modulation of nuclear factor- $\kappa \mathrm{B}$ and mitogen-activated protein kinase signaling cascades. Nutr Rev, 73, 348-358.

[92] Joven, J., Micol, V., Segura-Carretero, A., Alonso-Villaverde, C., \& Menéndez, J. A. (2014) Polyphenols and the modulation of gene expression pathways: can we eat our way out of the danger of chronic disease? Crit Rev Food Sci Nutr, 54, 985-1001. 
[93] Fujii, H., Iwase, M., Ohkuma, T., Ogata-Kaizu, S., Ide, H., Kikuchi, Y., Idewaki, Y., Joudai, T., Hirakawa, Y., Uchida, K., Sasaki, S., Nakamura, U., \& Kitazono, T. (2013) Impact of dietary fiber intake on glycemic control, cardiovascular risk factors and chronic kidney disease in Japanese patients with type 2 diabetes mellitus: the Fukuoka Diabetes Registry. Nutr J, 12,159 .

[94] Gopinath, B., Harris, D. C., Flood, V. M., Burlutsky, G., Brand-Miller, J., \& Mitchell, P. (2011) Carbohydrate nutrition is associated with the 5-year incidence of chronic kidney disease. J Nutr, 141, 433-439.

[95] Strippoli, G. F., Craig, J. C., Rochtchina, E., Flood, V. M., Wang, J. J., \& Mitchell, P. (2011) Fluid and nutrient intake and risk of chronic kidney disease. Nephrology, 16, 326-334.

[96] Díaz-López, A., Bulló, M., Basora, J., Martínez-González, M. Á., Guasch-Ferré, M., Estruch, R., Wärnberg, J., Serra-Majem, L., Arós, F., Lapetra, J., Ros, E., Pintó, X., Covas, M. I., \& Salas-Salvadó, J. (2013) Cross-sectional associations between macronutrient intake and chronic kidney disease in a population at high cardiovascular risk. Clin Nutr, 32, 606-612.

[97] Anderson, J. W., Baird, P., Davis, R. H. Jr., Ferreri, S., Knudtson, M., Koraym, A., Waters, V., \& Williams, C. L. (2009) Health benefits of dietary fiber. Nutr Rev, 67, 188-205.

[98] Kaczmarczyk, M. M., Miller, M. J., \& Freund, G. G. (2012) The health benefits of dietary fiber: beyond the usual suspects of type 2 diabetes mellitus, cardiovascular disease and colon cancer. Metabolism, 61, 1058-1066.

[99] Anderson, J. W., \& Jhaveri, M. (2012) Epidemiological studies of dietary fiber and cardiovascular disease. In: Dietary fiber and health. (Cho, S. S., Almeida, N., eds.), pp. 121, CRC Press LLC, Boca Raton, FL.

[100] Ciecierska, A., Drywień, M. E., Hamulka, J., \& Sadkowski, T. (2019) Nutraceutical functions of beta-glucans in human nutrition. Rocz Panstw Zakl Hig, 70, 315-324.

[101] Nicklas, T. A., O'neil, C., Slavin, J. L., \& Cho, S. S. (2012) Consumption of total fiber and types of fiber are associated with a lower prevalence of obesity and abdominal adiposity in U.S. adults. NHANES 1999-2006. In: Dietary fiber and health. (Cho, S. S., Almeida, N., eds.), pp. 71, CRC Press LLC, Boca Raton, FL.

[102] Koh-Banerjee, P., \& Rimm, E. B. (2003) Whole grain consumption and weight gain: a review of the epidemiological evidence, potential mechanisms and opportunities for future research. Proc Nutr Soc, 62, 25-29.

[103] Yao, B., Fang, H., Xu, W., Yan, Y., Xu, H., Liu, Y., Mo, M., Zhang, H., \& Zhao, Y. (2014) Dietary fiber intake and risk of type 2 diabetes: a dose-response analysis of prospective studies. Eur J Epidemiol, 29, 79-88.

[104] Anderson, J. W., Akanji, A. O., \& Randles, K. M. (2001) Treatment of diabetes with high-fiber diets. In: Handbook of dietary fiber in human nutrition. (Spiller, G. A., ed.), vol. 3, pp. 373, CRC Press LLC, Boca Raton, FL.

[105] Lairon, D., Arnault, N., Bertrais, S., Planells, R., Clero, E., Hercberg, S., \& Boutron-Ruault, M. C. (2005) Dietary fiber intake and risk factors for cardiovascular disease in French adults. Am J Clin Nutr, 82, 1185-1194.

[106] Piepoli, M. F., Hoes, A. W., Agewall, S., Albus, C., Brotons, C., Catapano, A. L., Cooney, M-T., Corrà, U., Cosyns, B., Deaton,
C., Graham, I., Hall, M. S., Hobbs, F. D. R., Løchen, M-L., Löllgen, H., Marques-Vidal, P., Perk, J., Prescott, E., Redon, J., Richter, D. J., Sattar, N., Smulders, Y., Tiberi, M., van der Worp, H. B., van Dis, I., \& Verschuren, W. H. M.(2016) 2016 European Guidelines on cardiovascular disease prevention in clinical practice. The Sixth Joint Task Force of the European Society of Cardiology and Other Societies on Cardiovascular Disease Prevention in Clinical Practice (constituted by representatives of 10 societies and by invited experts) Developed with the special contribution of the European Association for Cardiovascular Prevention \& Rehabilitation (EACPR). Eur Heart J, 37, 2315-2381.

[107] World Health Organization (2007) Prevention of cardiovascular disease. Guidelines for assessment and management of cardiovascular risk. pp. 1-86. WHO Press. Geneva, Switzerland.

[108] Takahashi, M. M., de Oliveira, E. P., de Carvalho, A. L. R., de Souza Dantas, L. A., Burini, F. H. P., Portero-McLellan, K. C., \& Burini, R. C. (2011) Metabolic syndrome and dietary components are associated with coronary artery disease risk score in free-living adults: a cross-sectional study. Diabetol Metab Syndr, 3, 7.

[109] Streppel, M. T., Ocké, M. C., Boshuizen, H. C., Kok, F. J., \& Kromhout, D. (2008) Dietary fiber intake in relation to coronary heart disease and all-cause mortality over $40 \mathrm{y}$ : the Zutphen Study. Am J Clin Nutr, 88, 1119-1125.

[110] Mente, A., de Koning, L., Shannon, H. S., \& Anand, S. S. (2009) A systematic review of the evidence supporting a causal link between dietary factors and coronary heart disease. Arch Intern Med, 169, 659-669.

[111] Pereira, M. A., O'Reilly, E., Augustsson, K., Fraser, G. E., Goldbourt, U., Heitmann, B. L., Hallmans, G., Knekt, P., Liu, S., Pietinen, P., Spiegelman, D., Stevens, J., Virtamo, J., Willett, W. C., \& Ascherio, A. (2004) Dietary fiber and risk of coronary heart disease: a pooled analysis of cohort studies. Arch Intern Med, 164, 370-376.

[112] Liu, S., Buring, J. E., Sesso, H. D., Rimm, E. B., Willett, W. C., \& Manson, J. E. (2002) A prospective study of dietary fiber intake and risk of cardiovascular disease among women. J. Am. Coll. Cardiol, 39. 49-56.

[113] Lu, L., Huang, Y. F., Wang, M. Q., Chen, D. X., Wan, H., Wei, L. B., \& Xiao, W. (2017) Dietary fiber intake is associated with chronic kidney disease (CKD) progression and cardiovascular risk, but not protein nutritional status, in adults with CKD. Asia Pac J Clin Nutr, 26, 598-605.

[114]Wallström, P., Sonestedt, E., Hlebowicz, J., Ericson, U., Drake, I., Persson, M., Gullberg, B., Hedblad, B., \& Wirfält, E. (2012) Dietary fiber and saturated fat intake associations with cardiovascular disease differ by sex in the Malmö Diet and Cancer Cohort: a prospective study. PLoS One, 7, e31637.

[115] Rimm, E. B., Ascherio, A., Giovannucci, E., Spiegelman, D., Stampfer, M. J., \& Willett, W. C. (1996) Vegetable, fruit, and cereal fiber intake and risk of coronary heart disease among men. JAMA, 275. 447-451.

[116] Katagiri, R., Goto, A., Sawada, N., Yamaji, T., Iwasaki, M., Noda, M., Iso, H., \& Tsugane, S. (2020) Dietary fiber intake and total and cause-specific mortality: the Japan Public Health Center-based prospective study. Am J Clin Nutr, 111, 1027-1035. 
[117] Kim, Y., \& Je, Y. (2014) Dietary fiber intake and total mortality: a meta-analysis of prospective cohort studies. Am J Epidemiol, $180,565-573$

[118] Türk, C., Neisius, A., Petrik, A., Seitz, C., Skolarikos, A., Thomas, K., Donaldson, J. F., Drake, T., Grivas, N., \& Ruhayel, Y. (2018) EAU Guidelines on Urolithiasis. European Association of Urology 2018. EAU Guidelines. Edn. Presented at the EAU Annual Congress London 2018. ISBN 978-94-92671-01-1. EAU Guidelines office, Arnhem, The Netherlands [Internet]. Available from: http://uroweb.org/guidelines/compilations-of-all-guidelines/.

[119] American Diabetes Association (2019) Lifestyle management: standards of medical care in diabetes-2019. Diabetes Care, 42, S46-S60.

[120] The Ministry of Agriculture, Forestry and Fisheries. (2020) WASHOKU, traditional dietary cultures of the Japanese [Internet]. Available from: https://www.maff.go.jp/e/japan_food/washoku/pdf/wasyoku_e nglish.pdf.

[121] Teng, G. G., Pan, A., Yuan, J. M., \& Koh, W. P. (2015) Food sources of protein and risk of incident gout in the Singapore Chinese Health Study. Arthritis Rheumatol, 67, 1933-1942.

[122] Van Elswyk, M. E., Weatherford, C. A., \& McNeill, S. H. (2018) A systematic review of renal health in healthy individuals associated with protein intake above the US Recommended Allowance in randomized controlled trials and observational studies. Adv Nutr, 9, 404-418.

[123] Devries, M. C., Sithamparapillai, A., Brimble, K. S., Banfield, L., Morton, R. W., \& Phillips, S. M. (2018) Changes in kidney function do not differ between healthy adults consuming higher- compared with lower- or normal-protein diets: A systematic review and meta-analysis. J Nutr, 148, 1760-1775.

[124] The World Health Organization, Food and Agriculture Organization, and United Nations University. (2007) Protein and amino acid requirements in human nutrition. Tech Rep Ser, 935.

[125] Japanese Society of Nephrology. (2018) Evidence-based clinical practice guideline for CKD 2018. pp. 1-133. Tokyo Igakusha. Tokyo.

[126] Dalbeth, N., Wong, S., Gamble, G. D., Horne, A., Mason, B., Pool, B., Fairbanks, L., McQueen, F. M., Cornish, J., Reid, I. R., \& Palmano, K. (2010) Acute effect of milk on serum urate concentrations: a randomized controlled crossover trial. Ann Rheum Dis, 69. 1677-1682.

[127] Garrel, D. R., Verdy, M., PetitClerc, C. Martin, C., Brulé, D., \& Hamet, P. (1991) Milk-and soy-protein ingestion; Acute effect on serum uric acid concentration. Am J Clin Nutr, 53, 665-669.
[128] Jenkins, D. J., Kendall, C. W., Vidgen, E., Augustin, L. S., van Erk, M., Geelen, A., Parker, T., Faulkner, D., Vuksan, V., Josse, R. G., Leiter, L. A., \& Connelly, P. W. (2001) High-protein diets in hyperlipidemia: effect of wheat gluten on serum lipids, uric acid, and renal function. Am J Clin Nutr, 74, 57-63.

[129] Hosojima, M., Kaseda, R., Kondo, H., Fujii, M., Kubota, M., Watanabe, R., Tanabe, N., Kadowaki, M., Suzuki, Y., \& Saito, A. (2016) Beneficial effects of rice endosperm protein intake in Japanese men with risk factors for metabolic syndrome: a randomized, crossover clinical trial. BMC Nutr, 2, 25.

[130] Umemura, S., Arima, H., Arima, S., Asayama, K., Dohi, Y., Hirooka, Y., Horio, T., Hoshide, S., Ikeda, S., Ishimitsu, T., Ito, M., Ito, S., Iwashima, Y., Kai, H., Kamide, K., Kanno, Y., Kashihara, N., Kawano, Y., Kikuchi, T., Kitamura, K., Kitazono, T., Kohara, K., Kudo, M., Kumagai, H., Matsumura, K., Matsuura, H., Miura, K., Mukoyama, M., Nakamura, S., Ohkubo, T., Ohya, Y., Okura, T., Rakugi, H., Saitoh, S., Shibata, H., Shimosawa, T., Suzuki, H., Takahashi, S., Tamura, K., Tomiyama, H., Tsuchihashi, T., Ueda, S., Uehara, Y., Urata, H., \& Hirawa, N. (2019) The Japanese Society of Hypertension Guidelines for the Management of Hypertension (JSH 2019). Hypertens Res, 42, 1235-1481.

[131] Tate, G. A., Mandell, B. F., Karmali, R. A., Laposata, M., Baker, D. G., Schumacher, H. R. Jr., \& Zurier, R. B. (1988) Suppression of monosodium urate crystal-induced acute inflammation by diets enriched with gamma-linolenic acid and eicosapentaenoic acid. Arthritis Rheum, 31, 1543-1551.

[132] Mozaffarian, D., \& Wu, J. H. Y. (2011) Omega-3 fatty acids and cardiovascular disease. J Am Coll Cardiol, 58, 2047-2067.

[133] Tani, Y., Asakura, K., Sasaki, S., Hirota, N., Notsu, A., Todoriki, H., Miura, A., Fukui M., \& Date, C. (2015) The influence of season and air temperature on water intake by food groups in a sample of free-living Japanese adults. Eur J Sawada, Clin Nutr, 69, 907-913.

[134] Neogi, T., Chen, C., Chiasson, C., Hunter, D. J., \& Zhang, Y. (2009) Drinking water can reduce the risk of recurrent gout attacks. Arthritis Rheum, 60 (suppl), S762.

[135] Terkeltaub, R., \& Edwards, N. L. (2013) Gout: Diagnosis and management of gouty arthritis and hyperuricemia. 3rd edition, p. 1-336. Professional Communications, Inc. NY.

[136] Japanese Urological Association., Japanese Society of Endourology., Japanese Society on Urolithiasis Research. (2013) Guidelines for Management of Urolithiasis.: 2 nd edition. pp. 93-116, Kanehara shuppan, Tokyo (in Japanese).

[137] Jakše, B., Jakše, B., Pajek, M., \& Pajek, J. (2019) Uric acid and plant-based nutrition. Nutrients, 11, 1736. 